\title{
Thyroid-disrupting chemicals and brain development: an update
}

\author{
Bilal B Mughal, Jean-Baptiste Fini and Barbara A Demeneix \\ CNRS/UMR7221, Muséum National d'Histoire Naturelle, Sorbonne Universités, Paris, France \\ Correspondence should be addressed to B A Demeneix: bdem@mnhn.fr
}

\begin{abstract}
This review covers recent findings on the main categories of thyroid hormone-disrupting chemicals and their effects on brain development. We draw mostly on epidemiological and experimental data published in the last decade. For each chemical class considered, we deal with not only the thyroid hormone-disrupting effects but also briefly mention the main mechanisms by which the same chemicals could modify estrogen and/or androgen signalling, thereby exacerbating adverse effects on endocrine-dependent developmental programmes. Further, we emphasize recent data showing how maternal thyroid hormone signalling during early pregnancy affects not only offspring IQ, but also neurodevelopmental disease risk. These recent findings add to established knowledge on the crucial importance of iodine and thyroid hormone for optimal brain development. We propose that prenatal exposure to mixtures of thyroid hormonedisrupting chemicals provides a plausible biological mechanism contributing to current increases in the incidence of neurodevelopmental disease and IQ loss.
\end{abstract}

\author{
Key Words \\ - thyroid \\ - endocrine disruptors \\ - neuroendocrinology
}

\section{Introduction}

Thyroid hormone (TH) is essential for normal brain development where it influences, during specific temporal windows, neurogenesis, neuronal migration, neuronal and glial cell differentiation, myelination and synaptogenesis. These TH-dependent processes are crucial during early gestation and postnatal development, and then continue, albeit at reduced rates, throughout adulthood. During the first 10-12 weeks of gestation, the foetus relies entirely on maternal TH. Hence, severe maternal TH deficiency adversely affects offspring neurodevelopment $(1,2)$. Recent epidemiological evidence suggests that even more moderate forms of maternal thyroid dysfunction may affect child cognitive development and increase the risk of neurodevelopmental disorders $(3,4,5,6)$. Therefore, it is important to gain a better understanding of early thyroid dysfunction on offspring neurodevelopment $(1,7)$.

Another major cause of thyroid dysfunction can be the presence of thyroid hormone-disrupting chemicals in the maternal and fetal environment. Endocrine-disrupting compounds (EDCs) are xenobiotics that modulate hormonal homeostasis thereby inducing adverse effects (8). Numerous EDCs identified to date contain a halogen group substitution with chlorine and bromine. Interestingly, THs are the only complex halogenated (iodine) molecules produced by and necessary for vertebrate homeostasis, making TH physiology highly vulnerable to EDCs. Halogen-substituted phenolic moieties can mimic natural THs and thereby interact with multiple aspects of hormone production, feedback, distribution, entry into cells, intracellular metabolism (deiodination, conjugation) of THs, as well as at the level of receptors, as antagonists or analogues.

The aim of this review is to provide an update on how different chemicals in the environment can disrupt thyroid signalling and thereby affect brain development. A number of previous reviews have addressed certain http://www.endocrineconnections.org https://doi.org/10.1530/EC-18-0029
() 2018 The authors Published by Bioscientifica Ltd
This work is licensed under a Creative Commons Attribution-NonCommercial-NoDerivatives 4.0 International License. 
aspects of this question. Notably, in 1998, BruckerDavis and colleagues (9) reviewed the different classes of chemicals that could affect thyroid signalling and Zoeller and Crofton (10) underlined how endocrine disruption affected early brain development. A decade later the situation was updated by Crofton (11) and by Boas and colleagues (12).

No new major classes of TH-disrupting chemicals have been characterised since the last review appeared. However, within classes certain novel compounds have attracted attention. Most often these new compounds have been introduced to replace a similar chemical for which adverse effects were reported. This has led to many examples of 'regrettable substitutions' within classes, cases of which are described below. Thus, our focus remains on perchlorate, phenols, pesticides, polychlorinated biphenyls (PCBs), poly brominated flame retardants, perfluorinated compounds (PFCs) and phthalates (Fig. 1). Many of these substances are classed as persistent organic pollutants (POPs) and were banned decades ago yet they remain environmentally relevant due to their previous high production volumes and exceptionally long half-lives.

\section{Perchlorate}

Perchlorate is a well-characterised inhibitor of the sodiumiodide symporter (NIS) that is expressed in the basal membrane of thyroid follicular cells and is critical for iodide uptake (13). Two other NIS inhibitor classes, nitrates and thiocyanates, are found at significant levels in human fluids, but in molar terms, they are respectively 240 and 15 times less active than perchlorate (14). However, their environmental levels are such that their combined effects should be more often taken into account $(15,16)$.

Given first, its wide-ranging uses as an oxidant in products ranging from in rocket fuel to airbags and second, its high stability, perchlorate contamination is widespread. Epidemiological data show that despite its short half-life ( $<8 \mathrm{~h}$ in humans), continual exposure means that the chemical is virtually ubiquitous in the US population (17). Epidemiological evidence showed that perchlorate levels were associated with TSH in women, and this association was stronger in women with $<100 \mu \mathrm{g} / \mathrm{L}$ urinary iodine (18). The relationship was even greater in women who smoke, related to the fact that cigarette smoke is a source of thiocyanate.

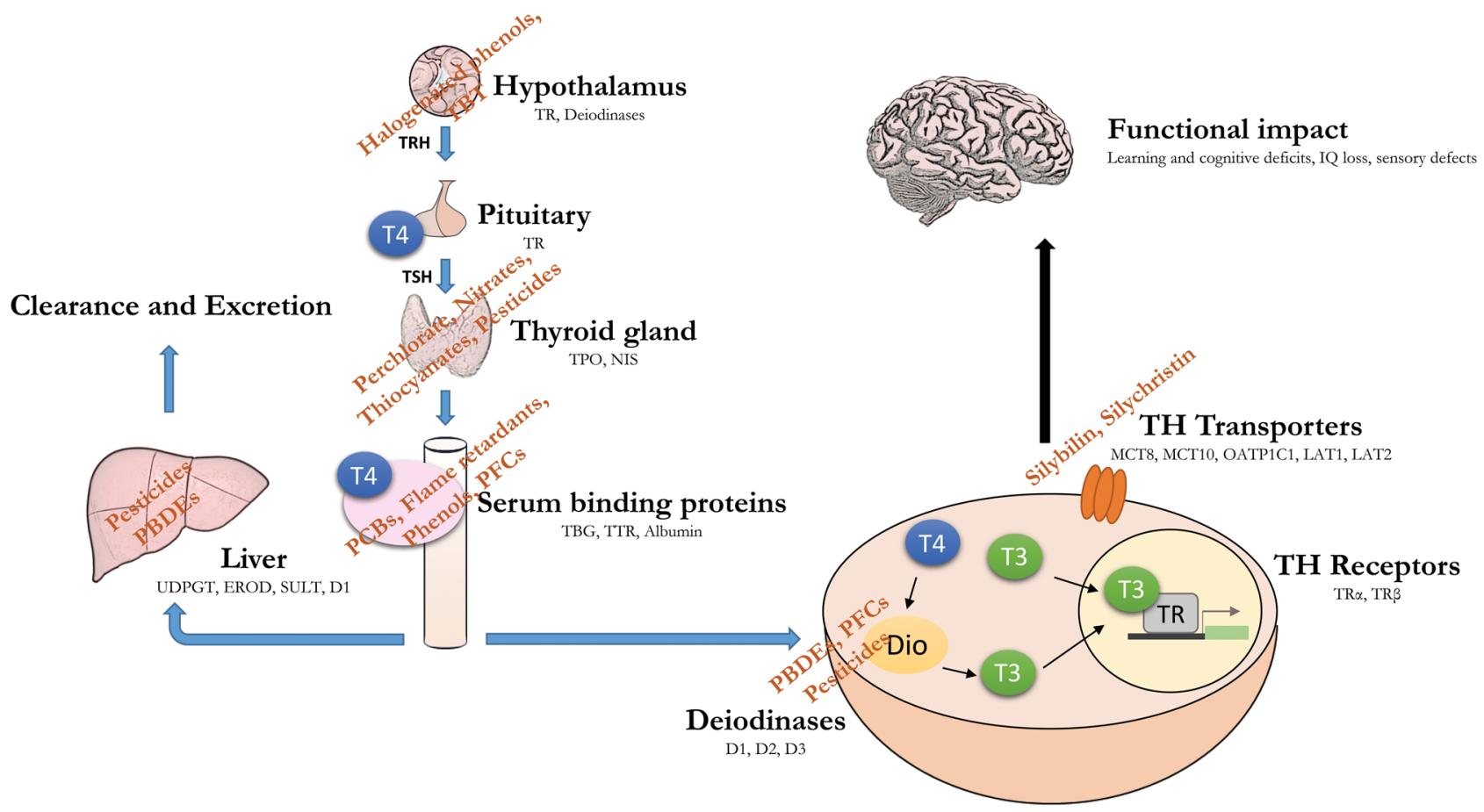

Figure 1

Endocrine-disrupting chemicals (EDCs) act at multiple levels of the hypothalamus-pituitary-thyroid (HPT) axis. Environmental chemicals have the potential to disrupt the HPT axis, alone or in combination. Given the crucial role for thyroid hormone in brain development, such disruption can have a long-lasting functional impact, such as IQ loss and increased risk of neurodevelopmental disease (note: targets not drawn to scale).

http://www.endocrineconnections.org @ 2018 The authors https://doi.org/10.1530/EC-18-0029
This work is licensed under a Creative Commons Attribution-NonCommercial-NoDerivatives 4.0 International License. 
Furthermore, recent epidemiological data analysed pregnant women for their thyroid status and perchlorate levels (19). Offspring born to those women that were both borderline hypothyroid and hypothyroxinemic and had higher perchlorate levels had a higher risk of being in the lowest $10 \%$ for IQ scores. The adverse effect of perchlorate was not modified by thyroxine therapy $(150 \mu \mathrm{g} /$ day) during pregnancy. However, it is possible that the timing of replacement (after 12 weeks pregnancy) was too late to exert corrective effects. Other recent data also link maternal perchlorate exposure to modified thyroid function during pregnancy (20). Iodine has long been known to be required for TH synthesis and both iodine deficiency and maternal hypothyroidism are risk factors for decreased IQ and neurodevelopmental disease $(21,22)$. It is worth noting that in the study cited (20), a large proportion of the women (74\%) had urinary iodine levels below the recommended median level $(150 \mu \mathrm{g} / \mathrm{L})$ for pregnancy, raising the question of whether iodine deficiency exacerbates the effects of perchlorate (and potentially other TH-disrupting chemicals). This question deserves far more research and needs to be taken into account in both epidemiological and experimental studies. Similarly, the presence of TH-disrupting chemicals has been identified as a confounder for epidemiological studies assessing effects of iodine supplementation during pregnancy (23).

\section{Phenols}

Two principal phenols are well-characterised $\mathrm{TH}$ disruptors, bisphenol A (BPA) and triclosan (TCS). Both have high production volumes and been so extensively used that they are now virtually ubiquitous contaminants of human fluids (24) and the environment (25).

\section{Bisphenol A (BPA, 4,4' isopropylidenediphenol)}

BPA is an organic synthetic compound, first identified as a synthetic estrogen in 1930s (26). Current common uses of BPA are in plastic products such as water bottles and food containers, CDs, DVDs, safety equipment, thermal paper and medical devices. In the United States, France and Denmark, BPA is restricted for certain uses, such as baby bottles. More recently, since 2015, France banned the use of BPA in plastic food containers. The same year (2015), EFSA maintained their opinion delivered in 2013 that BPA poses no health risks, but the committee lowered the tolerable daily intake from $50 \mu \mathrm{g} / \mathrm{kg} \mathrm{bw} /$ day to
$4 \mu \mathrm{g} / \mathrm{kg}$ bw/day (27). Despite these recent restrictions, there is still widespread exposure to BPA in human populations (28). It is retained in humans and has been found in pregnant women's serum, placenta and breast milk $(29,30,31,32,33,34)$. As restrictions were increasingly placed on BPA use, a number of structural BPA analogues such as bisphenol S (BPS), bisphenol F (BPF) and bisphenol $\mathrm{B}$ (BPB) were marketed. These analogues are found now in considerable quantities in human urine $(35,36,37$, 38). These replacement chemicals are often described as 'regrettable substitutions' as their EDC-related effects are apparently no less than those of BPA, including effects on TH signalling $(39,40)$ and estrogen receptor (ER) signalling (41).

As BPA is primarily thought of as an estrogen disruptor but is also a TH modulator. EDC action across endocrine systems is to be expected as crosstalk exists at multiple levels: from different nuclear receptors (42) to individual target genes and networks to physiological systems. As BPA can interact with multiple nuclear hormone receptors including ER (43), estrogen-related receptors (ERR) (44), $\operatorname{AR}(45,46)$ and thyroid hormone receptors (TR) $(39,47,48)$, potential crosstalk needs to be considered at multiple levels.

BPA and ER interaction has been reviewed extensively elsewhere, for both classical and non-classical estrogen receptors $(8,49)$. As to TRs, some experimental studies show that BPA does not bind to TR based on a competitive TR-binding test $(50,51,52)$, others show $\mathrm{T}_{3}$-TR-mediated agonistic and antagonistic effects of BPA (48, 53, 54). More recently, binding affinities of BPA and its analogues BPF and BPS, with TR were calculated in silico and found to be roughly similar (55). When tested by a spectrum of in vitro and in vivo methods, all three analogues activated $\mathrm{TH}$ signalling in the absence of $\mathrm{T}_{3}$ (39). The in vitro approaches included competitive binding assays, molecular docking and coactivator-binding assays, whereas the in vivo methodology exploited TH-response gene responses in Pelophylax nigromaculatus tadpoles.

In human epidemiology, studies have reported changes in TH parameters as a function of BPA exposure in adults $(56,57,58,59)$, including in pregnant women $(60,61,62)$. In pregnant women, maternal BPA levels were inversely (62) or positively (60) associated with $\mathrm{T}_{4}$ levels while two studies reported no association $(61,63)$. In humans, inverse associations of BPA with TSH have also been reported in both sexes (60) and in other cases, only in women (61). Yet another study reported a positive association (64). Such inconsistencies need to be examined notably for methodological differences between studies. 
We now focus specifically on BPA and TH and neurodevelopment. Increased prenatal BPA exposure is implicated in several sex-specific changes in child behaviour $(65,66,67,68,69,70)$. Prenatal BPA exposure is linked to increased internalizing behaviours in boys $(66,67,70)$ and increased risk of ADHD-related behaviour (65). In girls, prenatal BPA exposure has been associated with both internalising and externalising behaviours $(66,69)$, as well as poor executive function $(68)$. It is possible that differences in the results are due to varying timing of sample collection, exposure and assessment among the studies. Studies on postnatal childhood BPA exposure and effects on neurodevelopment are even more inconsistent. Some studies report a positive association of BPA levels with ADHD-linked behaviours in both girls and boys (71), and anxious, depressive or aggressive behaviours in girls $(66,67,72)$. Others report null association with childhood BPA exposure and neurodevelopmental outcomes $(68,73)$. Pubertal BPA exposure has also been associated with poorer cognitive performance in adolescence (74) and adulthood (75).

The lack of full endocrine profiles in these epidemiological studies makes it hard to pinpoint the exact mechanism linking endocrine disruption and neurodevelopmental outcome. Animal studies however can better define mode of action. Such studies link BPA levels with behavioural outcomes often associated with TH disruption including, hyperactivity (not sex specific) (76, 77), anxiety (78) and decreased motor activity (79). Prenatal BPA exposure in mice also results in mostly sexspecific changes in aggression and cognitive defects (80, $81,82,83,84,85)$. These sex-specific changes are not surprising due to the role of estrogen in differentiation of sexually dimorphic areas involved in behaviour and cognitive development (86). BPA exposure also causes epigenetic changes (methylation) on the $E R-\alpha$ gene in the cortex and hypothalamus of male and female mice and alters mRNA levels of DNA methyltransferases DNMT1 and DNMT3A $(78,87)$. Interestingly, DNMT3A is a wellknown TH-responsive gene, activated by liganded TRs $(88,89)$.

Halogenated BPAs include a bromine (Tetrabromobisphenol A, TBBPA) or chlorine (Tetrachlorobisphenol-A, TCBPA) substitute on the phenolic ring and are common flame retardants. TBBPA is currently the flame retardant with the highest production volume worldwide. It is found in printed electronic circuit boards and in plastics for electrical housings or piping. Due to its high production volume, toxicological effects attributed to TBBPA have been extensively reviewed by governments $(90,91,92)$ and deemed to have no health hazard, risk or concerns to humans. However, Van der Ven and colleagues (93) assessing multiple in vivo studies on rats concluded that the margin of exposure for humans was only 2.6 and that TBBPA exposure was a matter of concern for authorities.

What is more, TBBPA has been established in vitro as neurotoxicant that disrupts multiple intracellular pathways including zinc and calcium homeostasis, inducing oxidative stress $(94,95,96,97)$ as well as acting as a partial $\mathrm{GABA}_{\mathrm{A}}$ agonist at $0.1 \mu \mathrm{M}$ (98). So far, results for in vivo developmental toxicity are less consistent. The conclusions of Van der Ven et al. (93) for instance contrast with those of certain toxicologists $(99,100)$. Although Viberg and Eriksson (2011) reported more marked effects for PBDE 99 than TBBPA in neonatal mouse brain, they observed downregulation of a certain classes of nicotinic receptors in the frontal cortex with both chemicals (101). In our laboratory, studies on mice showed that gestational exposure to TBBPA decreased TRH receptor and melanocortin 4 receptor basal expression in pups, dramatically affecting $\mathrm{T}_{3}$-induced repression of these genes (102).

Some studies have reported neural defects, including impaired motor function in zebrafish (103). Similarly, Nakajima and colleagues reported behavioural effects of TBBPA administration in adult mice and differential accumulation of the chemical according to brain region (104). Further, Lilienthal et al. noted increased latency of hearing responses in a rat one generation study (105). Interestingly, development of the inner ear is known to be a TH-dependent process (106).

Significant reduction in circulating $\mathrm{T}_{4}$ is the most frequent phenotype seen across rodent studies as a function of TBBPA exposure $(93,107)$. $\mathrm{T}_{4}$ reductions could occur through activation of UDP-glucuronosyltransferase, UGT, which increases metabolism of $\mathrm{T}_{4}$ in the liver and subsequent reduction of serum $\mathrm{T}_{4}$ levels (108). In vitro, TBBPA competes with binding of transthyretin (TTR) and interferes with $\mathrm{T}_{3}$-dependent cell proliferation (109). In a fluorescent polarization assay, TBBPA was found to modulate both coactivator and co-repressor interactions with TR (110). TBBPA also shows TH-disrupting effects in amphibian models. In Rana rugosa, TBBPA displayed inhibitory effects on $\mathrm{T}_{3}$-induced tail shortening (111) and in Xenopus laevis, TBBPA exerted antagonistic effects in the presence of high TH levels, but agonistic activity with low TH levels (112). TBBPA has also been demonstrated as a TH disruptor using both the amphibian metamorphosis assay $(112,113)$ and the Xenopus embryonic thyroid assay 
(XETA) (114). In the latter study, TBBPA was further found to alter expression of $\mathrm{TH}$ target genes implicated in neural stem cell function and differentiation. Whether such effects extend to other proliferative brain regions during development remains to be investigated (115).

In rats, TBBPA exposure increases estrogen levels (108) and uterine tumours (116), effects thought to be related to inhibition of liver estradiol sulfotransferase (109). The combined effects of TBBPA, increasing estrogen and antagonising $\mathrm{TH}$ signalling could well interact to modify genetic and cellular responses, as well as inducing longer-term adverse physiological responses governing reproduction.

\section{Triclosan (TCS, 2,4,4-trichloro-hydroxy diphenyl ether)}

Triclosan (TCS) is a widely used chlorinated phenolic antimicrobial and antifungal agent. It has been used for over 40 years as an antiseptic, disinfectant or preservative in medical and personal care products such as hand soaps and shampoos, mouthwash, toothpaste and cosmetics. While it has been banned from soaps and body washes in the United States, it is still extensively used in skin care products and toothpaste. TCS has a short half-life in humans, that is it is rapidly absorbed, metabolized and eliminated (primarily via urine) with a median excretion half-life of $11 \mathrm{~h}$ after oral intake (117). Despite this rapid clearance, the over use of products containing TCS maintain permanent, but varying exposure. The most likely sources in humans are ingestion and skin absorption. TCS has been found in the majority of urine samples obtained via population-based studies in North America $(118,119)$. TCS has also been detected in human milk and pregnant women's urine $(120,121,122)$. EU has restricted TCS use as a preservative to a maximum concentration of $0.2 \%$ in mouthwashes and $0.3 \%$ in other categories (123). In the environment, TCS likely accumulates in sediments as it is a lipophilic compound with low aqueous solubility and is commonly found contaminant in solid and water compartments $(124,125)$.

Several animal studies have confirmed TCS to act as a TH-disruptive chemical. In pregnant rats, TCS decreases serum $\mathrm{T}_{3}$ and $\mathrm{T}_{4}$, disrupts pup sex ratio balance and lowers their body weights $(126,127,128)$. TH disruption is also evident during weaning rats when their mothers are exposed to triclosan $(126,127)$. In mice, decreased levels of $\mathrm{T}_{4}$ are also observed after a short-term oral exposure to triclosan $(129,130,131)$. In amphibian models, the North American bullfrog (Rana catesbeiana) and Xenopus laevis, TCS exposure results in the disruption of TH-dependent metamorphosis, marked metabolic disorders of the liver and modulation of innate immunity $(132,133,134)$.

In addition to $\mathrm{TH}$, numerous studies report adverse effects of TCS exposure on reproductive organ development in male rats i.e., decreased testosterone and sperm production (135), and early age of pubertal onset in female mice (136). In vitro assays have confirmed TCS to act as an estrogen agonist using ER $\alpha$ and $E R \beta$ reporter gene assays $(137,138,139)$ stimulate breast and ovarian cancer cell growth in vitro $(140,141)$ and magnifying the effects of ethinyl estradiol $(136,142)$. In rodent models, TCS, like TBBA (see above) inhibits estrogen sulfation by inhibiting sulfotransferases, thus preventing metabolism of estradiol into biologically inactive forms $(143,144,145)$ thereby increasing circulating estrogen levels (143). Similar effects are seen in sheep (144). It is worth noting that these same sulfotransferases metabolise TH as well.

Epidemiological studies have investigated the shortterm and long-term effect of TCS and TH parameters, with inconsistent findings (56, 146, 147, 148, 149, 150). Many report no significant disruptions in $\mathrm{TH}$ levels while some report only most marked effects $(149,151)$. Among the effects, some observe a positive association between TCS and total $\mathrm{T}_{3}$ (149) in adolescents, while others report an inverse association between TCS and $\mathrm{fT}_{3}$ (151) levels in pregnant women. A prospective study on prenatal TCS exposure recently reported reduced head circumference in boys but not girls (152).

\section{Flavonoids}

Flavonoids are phenols that occur as natural food items. Recent work identified the plant extract (Silybum) silymarin, and its derivatives silychristin and silybilin, as inhibitors of the membrane $\mathrm{TH}$ transporter, mct8 (slc16a2). Entry of both $\mathrm{T}_{3}$ and $\mathrm{T}_{4}$ into target cells is reduced (153). This feature highlights the possible, and little studied, effects of compounds that interact with membrane $\mathrm{TH}$ transporters.

\section{Pesticides}

Pesticide usage increased dramatically over the last century, arguably to keep up with the demands of a http://www.endocrineconnections.org https://doi.org/10.1530/EC-18-0029
() 2018 The authors Published by Bioscientifica Ltd
This work is licensed under a Creative Commons Attribution-NonCommercial-NoDerivatives 4.0 International License. 
growing population. However, many studies have shown that pesticide usage is excessive and that yields can be maintained even when halving pesticide use (154). Many pesticides exert toxicological effects, including on thyroid signalling. Notably, the European Food Safety Authority reported that of 287 pesticide files examined, 101 showed effects indicative of thyroid disruption (155). Even though many incriminated pesticides have now been banned, many of them are still in use in emerging economies. Further, many of these chemicals are persistent due to their long half-lives and remain in the environment long after their ban. Such pesticides are called legacy pesticides, with many being common environmental contaminants. Here, we choose a few examples of this latter category and some others that currently on the market, but are potentially problematic.

\section{Dichlorodiphenyltrichloroethane (DDT)}

Dichlorodiphenyltrichloroethane (DDT) is an organochlorine insecticide, first used in World War I to control malaria and typhus. Its initial notoriety arose due to widespread effects on wildlife described by Rachel Carlson in her 1962 book Silent Spring (156), notoriety that led to its ban in the United States by 1972 and worldwide by the Stockholm Convention on POPs later that decade. Despite the ban, it is still used in certain countries to fight against malaria and dengue fever (157). DDT, and its main metabolite dichlorodiphenyltrichloroethylene (DDE), are highly persistent, lipophilic compounds that bioaccumulate and are still found in significant amounts in the environment and in humans, including in pregnant women $(158,159,160)$. Prenatal exposure to $\mathrm{p}, \mathrm{p}^{\prime}$-DDT and $\mathrm{p}, \mathrm{p}^{\prime}$-DDE has been associated with obesity $(161,162)$ and a significant reduction in children's psychomotor neurodevelopment $(162,163,164,165,166,167,168)$, in some cases, in a sex-specific manner $(162,169,170)$. The latter is not surprising as DDT binds to and activates ERs in both reproductive and other tissues including the brain $(171,172)$. On the other hand, DDE has been shown to inhibit androgens from binding to their receptors (173, 174). In adolescent boys, DDE is associated with increased testosterone (175) and decreased luteinizing hormone (176) while DDT is associated with decreases in both luteinizing hormone and testosterone (176). In women, in utero exposure to DDT, as judged by umbilical cord levels, has been associated with an increased risk of breast cancer later in life (177).

DDT and its metabolites have also been confirmed as TH-disrupting chemicals through human epidemiological

$$
\text { http://www.endocrineconnections.org }
$$

studies $(158,178,179,180,181)$. Studies have found negative association with DDE and total $\mathrm{T}_{3}$ and $\mathrm{T}_{4}$ levels $(182,183)$ and a positive association with TSH levels (183); suggesting an anti-thyroid effect. In contrast, recent studies found a positive association of DDE with total $\mathrm{T}_{3}$ and $\mathrm{T}_{4}$ levels, and a non-significant TSH reduction in floriculture workers $(158,179)$. These differences could be due to different levels of exposure and/or exposure to additional chemicals and characteristics of the populations studied, such as iodine or thyroid status and genetic factors.

In experimental studies, rats exposed to DDE exposure exhibit lower free $\mathrm{T}_{4}$ levels. One target of DDT action on thyroid metabolism may be through the inhibition of TSHstimulated intracellular accumulation of cyclic adenosine monophosphate (cAMP) by the action of DDT on the TSH receptor $(184,185,186,187)$. The highly lipophilic DDT may also interfere indirectly with the TSH receptor by altering the phosphor-lipid composition of the thyroid cell membrane, rendering the TSH receptor unable to internalise and instead be released extracellularly in vesicle forms in the presence of DDT (188). These vesicles have been suggested to initiate autoimmunity favouring the development of Graves' disease (184). Mice exposed to DDE also exhibit reduced expression of TTR and Dio2 mRNA, which further explains the reduced free $\mathrm{T}_{4}$ levels observed $(189,190)$. Increased expression of several hepatic enzymes can further contribute to TH degradation (190). Another study in mice reported that DDT exposure was associated with increased peripheral conversion of $\mathrm{T}_{4}$ into $\mathrm{T}_{3}$, reduced TSH levels and morphological changes in the thyroid gland typical of iodine deficiency (191).

\section{Hexachlorobenzene (HCB)}

Hexachlorobenzene (HCB) is an organochloride, used primarily as a fungicide for seeds and as a woodpreserving agent. It was banned globally in 1979 under the Stockholm Convention on POPs as a pesticide. Its current main source is through the industrial emission as a by-product of the manufacture of chlorinated solvents and pesticides. It is extremely lipophilic and accumulates in the environment. It gained prominence during late 1950s when accidentally over-treated HCB-treated seeds were consumed by the general public in Turkey. Affected individuals, primarily children, displayed changed porphyrin metabolism, leading to porphyria cutanea tarda, enlarged liver and thyroid gland and osteoporosis (192, 193). Similar effects have been observed in HCB-exposed rats (194) i.e. hepatic and thyroid neoplasms $(195,196$, 197), porphyria $(193,198)$. Other epidemiological studies 
have found associations between lower levels of HCB and decreased gestational length (199), poor social competence (200) and increased body weight during childhood (201). Studies on floriculture workers have further revealed an association between HCB with decreased levels of total $\mathrm{T}_{4}$ $\left(\mathrm{TT}_{4}\right)$ (202) and $\mathrm{TT}_{3}$ (203). In animal studies, HCB is known to disrupt progesterone and estradiol concentrations $(204,205,206)$, impair reproductive efficiency $(207,208)$ and reduce neonatal viability and growth (209). It also disrupts levels of $\mathrm{T}_{3}$ and $\mathrm{T}_{4}(210,211)$, leads to goitre (212) and hypothyroidism (213). Disruption of the TH axis may partly be due to HCB's action on the activity and expression of hepatic Dio1 and Dio2 enzymes, respectively (214). In rats, HCB has been shown to induce apoptosis in the thyroid cells, most likely due to action on mitochondria through oxidative stress $(215,216)$. There is also evidence that HCB may competitively inhibit binding of thyroxine to serum carrier proteins $(214,215)$. More investigations are required to elucidate the exact mechanisms of HCB on TH signalling.

\section{Chlorpyrifos (CPF, 0,0-diethyl 0-(3,5,6-trichloro-2- pyridinyl) ester phosphorothioic acid)}

Chlorpyrifos is a member of the organophosphate class of insecticides that target the central and peripheral nervous system specifically inhibiting the enzyme activity of acetylcholinesterase (217). It is currently one of the most widely used insecticides in the United States and other countries, to manage insect pests on agricultural crop. CPF applications were once particularly heavy in urban areas, where the exposed populations included pregnant women $(218,219)$. Interestingly, its ban in household use in 2001 allowed for a natural experiment within an ongoing birth cohort study at Columbia University. Before the ban, decreases in birth weight and length were observed in association with CPF in newborn cord blood. After the ban, these outcomes disappeared (220). This result has been observed more recently (221), a result that is not surprising as CPF readily crosses the placenta (222). Further studies have reported prenatal CPF exposure association with impaired cognition and motor function (223), attention-deficit hyperactive disorder (224), deficits in working memory and reduced IQ (225) and tremors during childhood (226). While some groups have considered that the levels of CPF in cord blood are too low to induce adverse effects $(227,228)$, one needs to take into account that the half-life of CPF is approximatively $27 \mathrm{~h}$ (229). Thus, the possibility of substantially higher in utero levels of $\mathrm{CPF}$ is considerable. Despite these studies and its recent thorough evaluation by the World Health Organization (WHO) and Danish Environmental Protection Agency finding, toxicological evidence to be strong and the epidemiological evidence to be of moderate-to-high quality, the EPA denied a recent petition for ban calling it 'crucial to U.S. agriculture' (230). Not surprisingly, given the well-demonstrated epidemiological data showing negative effects on brain development, this decision has been severely criticised (231).

Given the importance of TH to brain development, the neurological and impaired cognitive outcomes associated with CPF exposure could well have underlying thyroid hormone-dependent mechanisms. Two studies based on analysis of NHANES data from the years 1999-2002 describe significant associations between levels of chlorpyrifos metabolite, 3,5,6-trichloro-2-pyridinol (TCPY) and thyroid parameters, namely increased $\mathrm{TT}_{4}$ in both males and females and decreased TSH levels in males, with increased TSH levels in females $(232,233)$.

In rat studies, a reduction in brain $\mathrm{T}_{4}$ levels is seen following prenatal CPF exposure whereas postnatal exposure results in a transient elevation in young adulthood (234). Mice exposed to low-dose CPF display reduced serum $\mathrm{T}_{4}$ levels and display altered thyroid follicular size, with an apparent higher vulnerability in males (235) and anxiety-like behaviour (236). Reduction of $\mathrm{T}_{4}$ in response to CPF has also been observed in rats (237), whereas exposure to CPF's methyl counterpart (chlorpyrifos-methyl) results in reduced $\mathrm{T}_{4}$ and increased TSH (hypothyroidism) (238). In our lab, CPF was shown to affect $\mathrm{TH}$ signalling using a transgenic reporter. Moreover, a short embryonic exposure impacts mature brain structure (Spirhanzlova P, Leemans M, Sébastien LE, Mughal BB, Wejaphikul K, Fini J-B, Visser T \& Demeneix BA, unpublished observations).

As to the effects on ER and AR signalling, CPF has been found to interfere with the ER $\beta$ mRNA steady state level $(239,240)$ and exert an ER $\alpha$-dependent estrogenic effect on cell proliferation in vitro (241) and in vivo (242). CPF also has anti-androgenic activity as Leydig cells from the rat exposed to $\mathrm{CPF}$ in vitro exhibit a significant decrease in testosterone biosynthesis (243). More epidemiological and experimental data are urgently needed as this pesticide is being assessed for renewal in the EU from 2019.

\section{Other pesticides}

As previously stated, more than a 100 of the 287 pesticides examined by European Food Safety Authority (EFSA) had features indicative of thyroid disruption (155). 
In the recent review of chemicals that could be used as reference for thyroid disruption screening, Wegner and colleagues identified a number of phytopharmaceuticals or biocides with TH-disrupting activity (244). To cite a few, their list contained different classes of fungicides and organophosphates, along with a number of juvenile hormone analogues. Among the fungicides, figure the ethylene bisdithiocarbamates (EBDC) e.g. maneb, mancozeb, ziram, zineb. Their common degradation product, ethylene thiourea (ETU), in addition to being a type IIB carcinogen, interferes with iodide organification by inhibiting thyroid peroxidase (TPO) (245) thereby decreasing thyroidal production of $\mathrm{T}_{3}$ and $\mathrm{T}_{4}$ in experimental animals (246, 247). In addition, the animals exhibit increased thyroid/body weight ratio, histopathological changes and reduced serum protein-bound iodine (246). Recent epidemiological data further underlines the importance of iodine status and the effect of ETU on thyroid function (248). Another class of fungicides with TH-disrupting activity are the azoles. This class of fungicide can enhance TH hepatic metabolism through the induction of enzymes uridine diphosphate-glucuronosyl-transferase (UDPGT), thereby increasing biliary elimination of $\mathrm{T}_{3}$ and $\mathrm{T}_{4}$ (249). Reduction of $\mathrm{TH}$ level varies considerably depending on the class of azoles (250).

The organophosphate insecticide malathion is an acetylcholinesterase inhibitor, similar to CPF, widely used in North American agriculture and residential landscapes, and in public health pest control programmes such as residential mosquito eradication. It has also been characterised as an inhibitor of teleost TPO (251) and TTR $(252,253)$. Other authors have documented increased levels of $\mathrm{T}_{3}$ and reduced $\mathrm{T}_{4}$ as a function of malathion exposure $(254,255)$. As it is currently an approved insecticide in North America and Europe, it is important to note that it has been associated with a strongly increased risk of thyroid cancer in spouses of pesticide applicators (256).

Pyrethroids are synthetic organic insecticides similar to the natural pyrethrins produced by the flowers of chrysanthemums. Due to their high lipophilicity and persistence, they are prone to bioaccumulation. Further, toxicological studies have demonstrated their potential to disrupt the endocrine system and exert developmental toxicity (257). Permethrin (PM), one of the most heavily used synthetic pyrethroids, exerts estrogenic effect in zebrafish (258) while other pyrethroids have been demonstrated as interfering with TRs (259), TTR binding (260) and Dio1 inhibition (261, 262). Several rat studies also suggest that pyrethroid insecticides alter serum TH levels, mostly increasing total $\mathrm{T}_{3}$ levels $(255,263,264,265)$.
Finally, a pyridine-based juvenile hormone analogue pesticide, Pyriproxyfen, has been suggested as a TH-active substance (244). This and other findings led us and colleagues to suspect it could be implicated in the increased incidence of Zika-induced microcephaly in north eastern Brazil (266), especially given its use at high levels in drinking water during the outbreak (266).

\section{Polychlorinated biphenyls (PCBs)}

PCBs are a class of organic man-made chemicals that were mass produced globally since the 1920s, until their commercial production ban in the United States in 1979. They were widely used as plasticizers, in hydraulic fluids, heat transfer fluids, lubricants and electrical equipment like capacitors and transformers. A total of 209 possible congeners exists, classed according to the number and position of chlorine atoms carried. PCBs can also be metabolized by hydroxylation to OH-PCBs. Due to their high chemical stability, PCBs do not readily break down and are still found in significant quantities throughout the environment and human fluids (267). PCBs and their metabolites are known to efficiently transfer from maternal to foetal blood via the placenta $(268,269)$ and to nursing children via milk $(270,271)$. Prenatal PCB exposure in human has been associated with increased risk of a number of TH-related disorders including, high BMI (272), IQ loss $(273,274,275)$, cognitive defects (23, $273,276,277,278)$, reduced visual recognition memory (274), attention and motor deficits $(276,279,280,281)$, increased risk of autism $(282,283)$ and ADHD (273, $284,285)$. In PCB-exposed adults, an increased risk of cardiovascular disease has been reported (286), as has a slightly increased risk of thyroid autoimmunity in men $(287,288)$.

Due to their physiochemical properties, PCBs have long been suspected to act as $\mathrm{TH}$ and other steroidal hormone analogues $(2,289)$. Numerous publications covering both epidemiological and experimental studies have confirmed the association of hydroxylated and non-hydroxylated PCBs with decreased TH levels, $\mathrm{T}_{4}$ (290, 291, 292) and $\mathrm{T}_{3}(292,293,294,295)$. In fact, serum hypothyroxinemia is the most frequently reported adverse health effect in human populations exposed to PCBs due to displacement of $\mathrm{T}_{4}$ from TTR and subsequent increase of metabolism (296). PCBs in cord blood have also been linked with low thyroidbinding globulin (TBG) (293) and high TSH levels (297, 298). In contrast to the latter study, a recent analysis of 
three cohorts revealed slightly lower levels of TSH with PCB-153 exposure (299).

In experimental studies, PCB and their metabolites demonstrate a clear association with reduced $\mathrm{TH}$ levels in animal models $(300,301,302)$ and induce longterm effects on behaviour and neurodevelopment $(303,304)$. More recent studies have highlighted other possible mechanisms of PCB action on additional TH axis components. TTR disruption may play a role in distribution of hydroxylated PCBs to the placenta and the brain as PCB metabolites are known competitors for TTR's $\mathrm{T}_{4}$-binding pocket $(296,305)$. PCB exposure suppresses NIS expression (301) through the Akt/FoxO3a/NIS pathway $(306,307)$. NIS suppression may also be due to inflammation by PCB exposure. The PCB-induced AhR/JNK pathway stimulates the production of cytokines and thereby suppresses NIS expression (308). Hydroxylated PCBs may also inhibit SULT-catalysed THs sulfation (309). A more recent study on infants found further an association between PCBs in maternal blood with high $\mathrm{T}_{3}$ and low $\mathrm{rT}_{3}$ in cord serum indicating possible action on deiodinases (310). Finally, iodine status can have a major impact on the effect of PCB exposure (23). A pilot study found that PCB exposure lessens the benefits of iodine supplementation during pregnancy in a borderline iodine-deficient group and higher PCB levels have a negative impact on the neurocognitive development of the offspring.

The importance of other endocrine systems especially the sex hormones must not be overlooked as many sexually dimorphic changes due to gestational PCB exposure have been reported. Gestationally PCB-exposed females pups display increased birth weight, higher locomotor behaviours, higher corticosterone concentrations while the males display increased anogenital distances (311, 312). Certain PCB metabolites have been shown to interact with the ERs acting either as agonists or antagonists (313, 314). On the other hand, one PCB metabolite (PCB104) exhibits both, AR antagonistic and ER agonist properties (315). PCBs may also induce estrogenicity indirectly through inhibition of the estrogen sulfotransferase (316).

\section{Polybrominated flame retardants}

PBDEs are widely used flame retardants being used in furniture, carpets, automobiles, electrical appliances and flame-retardant fabrics. PBDEs are lipophilic in nature and as they are not chemically bound to the substrate, they easily accumulate in the environment. High levels are found in diverse situations from house dust (317) to river sediments (318). There are 209 congeners of PBDEs, due to the different possible bromine substitutions on the biphenyl backbone. Similar to PCBs, hydroxylated PBDEs (OH-PBDEs) add to the complexity of chemical interactions and stability. Production and usage of the less brominated PBDEs were banned in Europe in 2004, and more recently extended to BDE-209 (or deca-BDE). As BDE-209, is the most highly brominated compound (10 bromines), it is easily broken down into less brominated congeners (318). However, general levels of PBDE are increasing despite the ban (see for instance: (319)). In the United States, despite similar restrictions and phase out of deca-PBDE at the end of 2013 (except for certain uses) the entire population have detectable levels of at least one PBDE congener in their blood (320).

As PBDEs are persistent, PBDE congeners are still found in significant amounts in the placenta (321), fetal blood (322), and breast milk (323). Early exposure of PBDEs has also been associated with decreased IQ, diminished language and reading abilities, increased problems with hyperactivity and attention, and poorer executive function in children $(324,325,326,327,328,329,330,331,332)$. Among these, two studies further observed sex-specific differences. Vuong et al. reported significantly poorer executive function among boys with higher concurrent BDE-153 and no associations in girls, while Sagiv et al., observed poorer executive function in girls with higher 4 PBDE (BDE-47, -99, -100, -153) concentrations, but not in boys $(327,333)$. These sex-specific differences need to be investigated further as other studies have revealed no statistically significant sex interactions $(328,329)$.

The biological mechanism for sex differences in PBDE exposure-related neurotoxicity remains unknown. These behavioural changes are not surprising as PBDEs are well known to pass the blood-brain barrier, accumulate in the central nervous system and induce developmental neurotoxicity (334). Neonatal rodents exposed to PBDEs exhibit behavioural changes $(335,336,337,338)$, with reduced hippocampal long-term potentiation, modified intracellular calcium homeostasis (339), oxidative stress (340) and reduced postsynaptic protein levels in the hippocampus (341). Poorer attention and executive function suggests that PBDEs may also target the prefrontal cortex region of the brain $(342,343)$.

The precise mechanism of PBDE action at a molecular level, still remains to be elucidated. Clearly, one plausible action of PBDEs is through its disruption of TH availability. Several epidemiological studies have reported increased TSH levels, lower total $\mathrm{T}_{4}$ and, in some studies greater

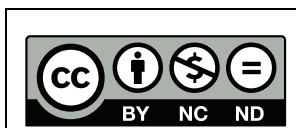

This work is licensed under a Creative Commons Attribution-NonCommercial-NoDerivatives 4.0 International License. 
free $\mathrm{T}_{3}$ levels in humans, including children $(295,344$, $345,346,347,348,349)$. These TH parameters are not always consistent and the differences in findings may be due to the median levels of PBDEs as demonstrated by a meta-analysis (350). High levels of PBDEs were positively correlated with $\mathrm{TSH} / \mathrm{T}_{4}$ levels while low PBDE levels were negatively associated. Decreased levels of $\mathrm{T}_{4}$ are, however, the most consistently observed adverse effect observed in populations, as a function of PBDE exposure. Decreased circulating TH levels have also been observed in experimental studies on rodents, fish and birds after exposure to perinatal PBDE (340, 351, 352, 353, 354). Further, PBDE congeners have been tested for their agonist and antagonist properties against TRs. Using a reporter gene assay, PBDE congeners, including hydroxylated compounds, inhibited TR-mediated transcription at varying concentrations $(355,356,357,358,359)$. The antagonist action of PBDEs on TR is further evident through its effect on purkinje cell dendrite arborisation and neural progenitor cell differentiation into the oligodendrocyte lineage $(360,361)$. In contrast, several hydroxylated PBDEs have been reported to act as agonists on TH-dependent transcription (355). Recently, using zebrafish knock down model of TR $\beta$, the developmental toxicity of PBDE was demonstrated (362).

Several hydroxylated PBDE congeners have been shown to bind to and alter $\mathrm{T}_{4}$ binding to the two $\mathrm{TH}$ distributor proteins, TBG and TTR $(363,364)$. The displacement of $\mathrm{T}_{4}$ from TTR and TBG, may lead to its increased glucuronidation, followed by decrease in circulating $\mathrm{T}_{4}$ and hence higher TSH. PBDEs and hydroxylated metabolites alter DIO2 activity in different astrocyte cell lines (365). BDE-99 decreased DIO2 activity by up to $80 \%$ while 3-OH-BDE-47, 6-OH-BDE-47, and 5-OH-BDE-99 also decreased DIO2 activity by 45-80\%. Multiple mechanisms appear to contribute to the decreased DIO2 activity, including weakened expression of DIO2 mRNA, competitive inhibition of DIO2, and enhanced post-translational degradation of DIO2. As astrocytes produce more than $50 \%$ of $\mathrm{T}_{3}$ used by the brain, Roberts et al. propose that PBDE exposure could compromise $\mathrm{T}_{3}$ delivery to the brain (365). A possible mechanism for this effect has been investigated in silico and thought to be halogen bonding of PBDEs to the active site selenocysteine (366). Studies have also found upregulation of Dio1 and Dio3, i.e. inducing local hyperthyroidism, in the periventricular zone of the brain, suggesting another, as yet under-estimated, mechanism impacting neurodevelopment. $(367,368)$.

http://www.endocrineconnections.org https://doi.org/10.1530/EC-18-0029

(C) 2018 The authors Published by Bioscientifica Ltd

\section{Phthalates}

Phthalates or phthalate esters are esters of phthalic acid and mainly used as plasticizers and softeners in various commercial products such as furniture, cosmetics, food packaging, and medical equipment such as catheters and perfusion bags/drips. Phthalates are also one of the most volatile EDCs and can be found at high concentrations in enclosed spaces where air conditioning is used, such as in vehicles (369). One of the most widely used phthalates is di-(2-ethylhexyl) phthalate (DEHP), used as a plasticizer in PVC recycling, but not manufacturing. This phthalate used in soft medical devices and toys was of major concern due to its high migration rate (370) and to the vulnerable population in contact with the compound. Consequently production was banned and manufacturing ceased by BASF in 2002. Other notable common phthalates are dibutyl phthalate (DBP) and its metabolite monobutyl phthalate (MBP), mono-(2-ethylhexyl) phthalate (MEHP), monoethyl phthalate (MEP), benzylbutylphthalate (BBP), diisodecyl phthalate (DIDP), and diisononyl phthalate (DINP). Alternatives to phthalate such as hexamoll Dinch are now being used in medical devices. A transgenerational study carried out by BASF in 2005, unpublished but described in EFSA 2006 (371) and NICNAS 2012 (372) reports, showed significant hepatic effects and thyroid hyperplasia induced by Dinch (372).

Phthalates do not bio-accumulate in the environment but since they are ubiquitous in our daily life, the potential of consequences of continuous exposure has raised concerns. Current EU legislation focuses on levels in children's toys. Some phthalates (DEHP, BBP and DBP) cannot be used in toys and childcare products. Other phthalates (DINP and DIDP) are banned only from toys that could be potentially placed in mouth. Urinary levels of phthalates serve as a good biomarker and high exposure levels have been found in the general public, including pregnant women $(373,374,375,376,377)$.

In humans, DEHP and its metabolites measured in maternal urine have been associated with adverse neurodevelopment and behaviour in offspring $(378,379$, 380, 381, 382). Interestingly, the phthalate metabolites, MEHHP, MEOHP and MBP were associated with both mental and behaviour defects in male but not female infants of 6 months (378). Prenatal exposure to phthalates has also been associated with 'reduced masculine play' among boys of 3- to 6-year (383). In contrast, Téllez-Rojo et al. reported lower scores on the mental developmental index (Bayley's test) in females but not males at 2-3 years 
(380). These sex-specific differences seem to attenuate with age (7-9 age) (384). More studies are needed to determine if gender differences are found as a function of phthalate exposure in older children. While these previous studies have focused on cognitive and behavioural defects during early years, other studies have found association between phthalates and more severe neurodevelopmental defects during school ages such a reduced IQ (385) and attentiondeficit disorder (ADD) (386).

As for a number of pesticides, these negative effects on brain development can be linked to changes in TH levels. In pregnant women, urinary MBP, MEP and MEHP have been associated with low serum $\mathrm{T}_{4}$ and $\mathrm{fT}_{4}$ during the second trimester $(387,388,389,390,391,392)$. These inverse relationships between MEHP and DEHP and $\mathrm{T}_{4}$ levels have been reported in the adult population including men $(59,393)$. In children, there are varying reports of levels of phthalates and its effect on TH levels. Some report inverse relations between the two (388, $394)$, others a positive relation (59), and one that relied on a relatively small cohort found none at all (395). This highlights the importance of study design, age group, sample size, and exposure profiles when studying nonpersistent chemicals.

Since DBP down-regulates the human NIS promoter (396), modulating the transcriptional activity of NIS may be one of the underlying causes of thyroid hyperactivity and decreased circulating $\mathrm{T}_{4}$ concentrations. DBP also appears to act as a thyroid antagonist when assessed through reporter gene assays (397). Zebrafish and male rats exposed to varying concentrations for MEHP and DEHP respectively demonstrate similar low levels of whole body $\mathrm{T}_{4}$ levels $(398,399)$. It is interesting to note that in 2017, ECHA classified DPB, DEHP, BBP and DIBP as substances of high concern due to their endocrinedisrupting properties.

\section{Perfluorinated compounds}

Perfluorinated chemicals (PFCs) are widely used in the manufacture of fabrics, carpets, surfactants, emulsifiers, Teflon, lubricants, cosmetics, and fire-fighting foams. They are commonly used as surfactants due to their fully fluorinated linear carbon chain attached to a hydrophilic head. Surfactants are compounds that lower the surface tension between two liquids or between a liquid and a solid and therefore are used in detergents, wetting agents, emulsifiers, foaming agents, and dispersants. They are also highly stable and therefore extremely persistent in the environment including both wildlife and human populations (400). Between the years 2000 and 2002, the main producers discontinued production of certain PFCs, including perfluorohexane sulfonate (PFHxS), perfluorooctanoate (PFOA) and perfluorooctane sulfonate (PFOS). Following its discontinuation, a significant decrease in the serum levels of PFOA and PFOS were observed $(401,402,403)$. However, another factor that needs to be taken into consideration is their relatively long half-life in humans being approximately 3.8 years for PFOA, 5.4 years for PFOS, and 8.5 years for PFHxS (404). Despite the ban, they are still found in significant levels in drinking water. A 2016 study covering 2/3 of drinking water supplies in the United States found unsafe levels of PFCs at the minimum reporting levels required by the EPA (405). PFOS has been banned in the EU since 2008 but there are no restrictions on PFOA and PFHxS. In the USA, the EPA launched a voluntary campaign in which the companies committed to reduce global facility emissions and product content of PFOA and related chemicals by 2015. The last update for this reduction was in 2013/2014.

Several animals studies have shown low-dose exposure of PFCs during neonatal development results in irreversible neurotoxic effects and alterations in spontaneous behaviour, habituation capability, learning and memory (assessed at 4 months) $(406,407)$. PFCs were also shown to alter the levels of synaptophysin and tau proteins in the cerebral cortex and hippocampus. Both proteins are important for the formation and growth of dopaminergic synapses and alterations in the dopamine transporters and receptors are one of the underlying causes of behavioural defects such as ADHD $(408,409)$. Several cross-sectional studies have investigated the potential association between PFC levels in school-age children and ADHD (410, 411). Hoffman et al. (410) reported a positive association between levels of PFOS, PFOA and PFHxS with ADHD symptoms while Stein and Savitz (411) reported an association with only PFHxS. High impulsivity has also been reported in children with high PFC levels (412) and high levels of PFOS exposure during pregnancy have been associated with delayed motor development in the first two years of life $(413,414)$. TH dysfunction is a wellestablished risk for $\operatorname{ADHD}(5,415,416,417,418)$.

PFC exposure and $\mathrm{TH}$ disruption have also been reported in adults. A large study of employees in a PFC manufacturer revealed negative associations between PFOA and free $\mathrm{T}_{4}$ levels (419). In the US, women with high levels of PFOA and men with high levels of PFOS are also at increased risk of thyroid diseases (420). Low levels of $\mathrm{T}_{4}$ as a function of PFC exposure have also been confirmed 
in several animal models. A single dose of PFOS in adult rats resulted in an initial increased $\mathrm{fT}_{4}$ and decreased $\mathrm{TSH}$ levels, followed by decrease in total $\mathrm{T}_{4}$ and $\mathrm{T}_{3}$ levels (421). In other adult rat studies, PFOA exposure resulted in decreased $\mathrm{T}_{4}$ levels $(422,423)$. Perinatal exposure to PFOS also results in decreased levels of $\mathrm{T}_{4}$ in both the mother and the offspring $(424,425,426,427)$. A test of twentyfour PFCs revealed competitive binding of most PFCs to TTR (428) which in turn can explain the dysfunctional levels of $\mathrm{T}_{4}$ observed in humans and animal models. Of the 24 PFCs, PFHxS displayed the highest competitive binding followed by PFOA and PFOS equally. PFOS has also been shown to decrease hepatic Dio1 mRNA while increasing thyroidal Dio1 mRNA (429). Whether this is a direct effect on Dio1 transcription or a response to levels of $\mathrm{T}_{4}$, is not yet clear.

\section{Conclusion}

The above review covers the main categories of chemicals that affect thyroid signalling. However, we have not reported environmental and human levels of exposure for each chemical class or effects of mixtures. There are wide variations in exposure to individual chemical exposure due to geographical location and legislation of the country of residence. Moreover, as we are exposed to multiple chemicals at a given time, it is increasingly important to address the effect of chemicals as a mixture, since synergistic effects of chemical mixtures without individual effects have been reported $(430,431)$. Our laboratory has shown that exposure to mixtures of common chemicals found in human amniotic fluid, alter TH signalling, brain structure and behaviour $(432,433)$. Together, these findings highlight the current impact of EDC exposure on neurodevelopment and argue for rapid public health intervention.

\section{Declaration of interest}

$B B M$ and J B F have nothing to disclose. B D is a cofounder of WatchFrog.

\section{Funding}

This work was supported by grants from Centre National de la Recherche Scientifique, Muséum National d'Histoire Naturelle and European Union Contracts DevCom FP7-People-2013-ITN N607142, H2020_EDC MIX RISK_ GA N${ }^{\circ} 634880$ and H2020_HBM4EU_GA n Contract No. 733032.

\section{References}

1 Moog NK, Entringer S, Heim C, Wadhwa PD, Kathmann N \& Buss C. Influence of maternal thyroid hormones during gestation on fetal brain development. Neuroscience 2017342 68-100. (https://doi. org/10.1016/j.neuroscience.2015.09.070)

2 Gilbert ME, Rovet J, Chen Z \& Koibuchi N. Developmental thyroid hormone disruption: prevalence, environmental contaminants and neurodevelopmental consequences. Neurotoxicology 201233 842-852. (https://doi.org/10.1016/j.neuro.2011.11.005)

3 Henrichs J, Bongers-Schokking JJ, Schenk JJ, Ghassabian A, Schmidt HG, Visser TJ, Hooijkaas H, de Muinck Keizer-Schrama SM, Hofman A, Jaddoe VV, et al. Maternal thyroid function during early pregnancy and cognitive functioning in early childhood: the generation R study. Journal of Clinical Endocrinology and Metabolism 201095 4227-4234. (https://doi.org/10.1210/jc.2010-0415)

4 Stagnaro-Green A \& Pearce E. Thyroid disorders in pregnancy. Nature Reviews Endocrinology 20128 650-658. (https://doi.org/10.1038/ nrendo.2012.171)

5 Päkkilä F, Männistö T, Pouta A, Hartikainen AL, Ruokonen A, Surcel HM, Bloigu A, Vääräsmäki M, Järvelin MR, Moilanen I, et al. The impact of gestational thyroid hormone concentrations on ADHD symptoms of the child. Journal of Clinical Endocrinology and Metabolism 201499 E1-E8. (https://doi.org/10.1210/jc.2013-2943)

6 Korevaar TIM, Muetzel R, Medici M, Chaker L, Jaddoe VW, de Rijke YB, Steegers EA, Visser TJ, White T, Tiemeier H, et al. Association of maternal thyroid function during early pregnancy with offspring IQ and brain morphology in childhood: a populationbased prospective cohort study. Lancet Diabetes and Endocrinology 20164 35-43. (https://doi.org/10.1016/S2213-8587(15)00327-7)

7 Fetene DM, Betts KS \& Alati R. Mechanisms in endocrinology maternal thyroid dysfunction during pregnancy and behavioural and psychiatric disorders of children: a systematic review. European Journal of Endocrinology 2017177 R261-R273. (https://doi. org/10.1530/EJE-16-0860)

8 Gore AC, Chappell VA, Fenton SE, Flaws JA, Nadal A, Prins GS, Toppari J \& Zoeller RT. Executive summary to EDC-2: the Endocrine Society's second Scientific Statement on endocrine-disrupting chemicals. Endocrine Reviews 201536 593-602. (https://doi. org/10.1210/er.2015-1093)

9 Brucker-Davis F. Effects of environmental synthetic chemicals on thyroid function. Thyroid $1998 \mathbf{8}$ 827-856. (https://doi.org/10.1089/ thy.1998.8.827)

10 Zoeller RT \& Crofton KM. Thyroid hormone action in fetal brain development and potential for disruption by environmental chemicals. Neurotoxicology 200021 935-945.

11 Crofton KM. Thyroid disrupting chemicals: mechanisms and mixtures. International Journal of Andrology 200831 209-222. (https:// doi.org/10.1111/j.1365-2605.2007.00857.x)

12 Boas M, Main KM \& Feldt-Rasmussen U. Environmental chemicals and thyroid function: an update. Current Opinion in Endocrinology, Diabetes and Obesity 200916 385-391. (https://doi.org/10.1097/ MED.0b013e3283305af7)

13 Dohán, O, Portulano C, Basquin C, Reyna-Neyra A, Amzel LM \& Carrasco N. The Na+/I symporter (NIS) mediates electroneutral active transport of the environmental pollutant perchlorate. PNAS 2007 104 20250-20255.

14 Tonacchera M, Pinchera A, Dimida A, Ferrarini E, Agretti P, Vitti P, Santini F, Crump K \& Gibbs J. Relative potencies and additivity of perchlorate, thiocyanate, nitrate, and iodide on the inhibition of radioactive iodide uptake by the human sodium iodide symporter. Thyroid 200414 1012-1019. (https://doi.org/10.1089/ thy.2004.14.1012)

15 Demeneix B. Losing Our Minds: How Environmental Pollution Impairs Human Intelligence and Mental Health. Oxford, UK: Oxford University Press, 2014. (https://doi.org/10.1093/acprof: oso/9780199917518.001.0001)

16 Suh M, Abraham L, Hixon JG \& Proctor DM. The effects of perchlorate, nitrate, and thiocyanate on free thyroxine for potentially sensitive subpopulations. The 2001-2002 and 2007-2008 National Health and Nutrition Examination Surveys. Journal of 
Exposure Science and Environmental Epidemiology 201424 579-587. (https://doi.org/10.1038/jes.2013.67)

17 Zoeller TR. Environmental chemicals targeting thyroid. Hormones 20109 28-40. (https://doi.org/10.14310/horm.2002.1250)

18 Blount BC, Valentin-Blasini L, Osterloh JD, Mauldin JP \& Pirkle JL. Perchlorate exposure of the US population, 2001-2002. Journal of Exposure Science and Environmental Epidemiology 200717 400-407. (https://doi.org/10.1038/sj.jes.7500535)

19 Taylor PN, Okosieme OE, Murphy R, Hales C, Chiusano E, Maina A, Joomun M, Bestwick JP, Smyth P, Paradice R, et al. Maternal perchlorate levels in women with borderline thyroid function during pregnancy and the cognitive development of their offspring: data from the controlled antenatal thyroid study. Journal of Clinical Endocrinology and Metabolism 201499 4291-4298. (https://doi. org/10.1210/jc.2014-1901)

20 Steinmaus C, Pearl M, Kharrazi M, Blount BC, Miller MD, Pearce EN Valentin-Blasini L, DeLorenze G, Hoofnagle AN \& Liaw J. Thyroid hormones and moderate exposure to perchlorate during pregnancy in women in southern California. Environmental Health Perspectives 2016124 861-867. (https://doi.org/10.1289/ehp.1409614)

21 Rayman MP \& Bath SC. The new emergence of iodine deficiency in the UK: consequences for child neurodevelopment. Annals of Clinical Biochemistry 201552 705-708. (https://doi. org/10.1177/0004563215597249)

22 Andersen SL, Laurberg P, Wu CS\& Olsen J. Attention deficit hyperactivity disorder and autism spectrum disorder in children born to mothers with thyroid dysfunction: a Danish nationwide cohort study. British Journal of Obstetrics and Gynaecology 2014121 1365-1374. (https://doi.org/10.1111/1471-0528.12681)

23 Brucker-Davis F, Ganier-Chauliac F, Gal J, Panaïa-Ferrari P, Pacini P, Fénichel P \& Hiéronimus S. Neurotoxicant exposure during pregnancy is a confounder for assessment of iodine supplementation on neurodevelopment outcome. Neurotoxicology and Teratology 2015 51 45-51. (https://doi.org/10.1016/j.ntt.2015.07.009)

24 Provencher G, Bérubé R, Dumas P, Bienvenu JF, Gaudreau E, Bélanger P \& Ayotte P. Determination of bisphenol A, triclosan and their metabolites in human urine using isotope-dilution liquid chromatography-tandem mass spectrometry. Journal of Chromatography A 20141348 97-104. (https://doi.org/10.1016/j. chroma.2014.04.072)

25 Tato T, Salgueiro-González N, León VM, González S \& Beiras R. Ecotoxicological evaluation of the risk posed by bisphenol A, triclosan, and 4-nonylphenol in coastal waters using early life stages of marine organisms (Isochrysis galbana, Mytilus galloprovincialis, Paracentrotus lividus, and Acartia clausi). Environmental Pollution 2017232 173-182. (https://doi.org/10.1016/j.envpol.2017.09.031)

26 Dodds EC \& Lawson W. Synthetic estrogenic agents without the phenanthrene nucleus. Nature 1936137 996-996. (https://doi. org/10.1038/137996a0)

27 EFSA. Scientific opinion on the risks to public health related to the presence of bisphenol A (BPA) in foodstuffs. EFSA Journal 201513 3978 .

28 Andra SS, Charisiadis P, Arora M, Van Vliet-Ostaptchouk JV \& Makris KC. Biomonitoring of human exposures to chlorinated derivatives and structural analogs of bisphenol A. Environment International 201585 352-379. (https://doi.org/10.1016/j. envint.2015.09.011)

29 Lee J, Choi K, Park J, Moon HB, Choi G, Lee JJ, Suh E, Kim HJ, Eun SH, Kim GH, et al. Bisphenol A distribution in serum, urine, placenta, breast milk, and umbilical cord serum in a birth panel of mother-neonate pairs. Science of the Total Environment $2017 \mathbf{6 2 6}$ 1494-1501. (https://doi.org/10.1016/j.scitotenv.2017.10.042)

30 Cantonwine DE, Meeker JD, Ferguson KK, Mukherjee B, Hauser R \& McElrath TF. Urinary concentrations of bisphenol A and phthalate metabolites measured during pregnancy and risk of preeclampsia. Environmental Health Perspectives 2016124 1651-1655.
31 Troisi J, Mikelson C, Richards S, Symes S, Adair D, Zullo F \& Guida M. Placental concentrations of bisphenol A and birth weight from births in the Southeastern U.S. Placenta 201435 947-952. (https://doi. org/10.1016/j.placenta.2014.08.091)

32 Vela-Soria F, Jiménez-Díaz I, Rodríguez-Gómez R, Zafra-Gómez A, Ballesteros O, Fernández MF, Oleab N \& Navalón A. A multiclass method for endocrine disrupting chemical residue analysis in human placental tissue samples by UHPLC-MS/MS. Analytical Methods 2011 3 2073. (https://doi.org/10.1039/c1ay05162h)

33 Mendonca K, Hauser R, Calafat AM, Arbuckle TE \& Duty SM. Bisphenol A concentrations in maternal breast milk and infant urine. International Archives of Occupational and Environmental Health 2014 87 13-20. (https://doi.org/10.1007/s00420-012-0834-9)

34 Deceuninck Y, Bichon E, Marchand P, Boquien CY, Legrand A, Boscher C, Antignac JP \& Le Bizec B. Determination of bisphenol $\mathrm{A}$ and related substitutes/analogues in human breast milk using gas chromatography-tandem mass spectrometry. Analytical and Bioanalytical Chemistry 2015407 2485-2497. (https://doi. org/10.1007/s00216-015-8469-9)

35 Ye X, Wong LY, Kramer J, Zhou X, Jia T \& Calafat AM. Urinary concentrations of bisphenol A and three other bisphenols in convenience samples of U.S. adults during 2000-2014. Environmental Science and Technology 201549 11834-11839. (https://doi. org/10.1021/acs.est.5b02135)

36 Yang Y, Guan J, Yin J, Shao B \& Li H. Urinary levels of bisphenol analogues in residents living near a manufacturing plant in south China. Chemosphere 2014112 481-486. (https://doi.org/10.1016/j. chemosphere.2014.05.004)

37 Yang YJ, Li ZL, Zhang J, Yang Y \& Shao B. Simultaneous determination of bisphenol A, bisphenol AF, tetrachlorobisphenol $\mathrm{A}$, and tetrabromobisphenol A concentrations in water using on-line solid-phase extraction with ultrahigh-pressure liquid chromatography tandem mass spectrometry. International Journal of Environmental Analytical Chemistry 201494 16-27. (https://doi.org/10 .1080/03067319.2013.853756)

38 Thayer KA, Taylor KW, Garantziotis S, Schurman SH, Kissling GE, Hunt D, Herbert B, Church R, Jankowich R, Churchwell MI, et al. Bisphenol a, bisphenol s, and 4-hydro xyphenyl 4-isopro oxyphenyl sulfone (bpsip) in urine and blood of cashiers. Environmental Health Perspectives 2016124 437-444. (https://doi.org/10.1289/ ehp.1409427)

39 Zhang Y-F, Ren XM, Li YY, Yao XF, Li CH, Qin ZF \& Guo LH. Bisphenol A alternatives bisphenol $\mathrm{S}$ and bisphenol $\mathrm{F}$ interfere with thyroid hormone signaling pathway in vitro and in vivo. Environmental Pollution 2017 [epub]. (https://doi.org/10.1016/j. envpol.2017.11.027)

40 Lee S, Kim C, Youn H \& Choi K. Thyroid hormone disrupting potentials of bisphenol A and its analogues - in vitro comparison study employing rat pituitary (GH3) and thyroid follicular (FRTL-5) cells. Toxicology in Vitro 201740 297-304. (https://doi.org/10.1016/j. tiv.2017.02.004)

41 Le Fol V, Aït-Aïssa S, Sonavane M, Porcher JM, Balaguer P, Cravedi JP, Zalko D \& Brion F. In vitro and in vivo estrogenic activity of BPA, BPF and BPS in zebrafish-specific assays. Ecotoxicology and Environmental Safety 2017142 150-156. (https://doi.org/10.1016/j. ecoenv.2017.04.009)

42 MacKay H \& Abizaid A. A plurality of molecular targets: The receptor ecosystem for bisphenol-A (BPA). Hormones and Behavior 2017 [epub]. (https://doi.org/10.1016/j.yhbeh.2017.11.001)

43 Okada H, Tokunaga T, Liu X, Takayanagi S, Matsushima A \& Shimohigashi Y. Direct evidence revealing structural elements essential for the high binding ability of bisphenol a to human estrogen-related receptor-gamma. Environmental Health Perspectives 2008116 32-38. (https://doi.org/10.1289/ehp.10587)

44 Matsushima A, Kakuta Y, Teramoto T, Koshiba T, Liu X, Okada H, Tokunaga T, Kawabata S, Kimura M \& Shimohigashi Y. Structural

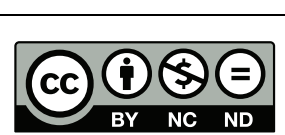

This work is licensed under a Creative Commons Attribution-NonCommercial-NoDerivatives 4.0 International License. 
evidence for endocrine disruptor bisphenol A binding to human nuclear receptor ERR. Journal of Biochemistry 2007142 517-524. (https://doi.org/10.1093/jb/mvm158)

45 Xu LC, Sun H, Chen JF, Bian Q, Qian J, Song L \& Wang XR. Evaluation of androgen receptor transcriptional activities of bisphenol A, octylphenol and nonylphenol in vitro. Toxicology 2005 216 197-203. (https://doi.org/10.1016/j.tox.2005.08.006)

46 Teng C, Goodwin B, Shockley K, Xia M, Huang R, Norris J, Merrick BA, Jetten AM, Austin CP \& Tice RR. Bisphenol A affects androgen receptor function via multiple mechanisms. ChemicoBiological Interactions 2013203 556-564. (https://doi.org/10.1016/j. cbi.2013.03.013)

47 Zoeller RT, Bansal R \& Parris C. Bisphenol-A, an environmental contaminant that acts as a thyroid hormone receptor antagonist in vitro, increases serum thyroxine, and alters RC3/neurogranin expression in the developing rat brain. Endocrinology 2005146 607-612. (https://doi.org/10.1210/en.2004-1018)

48 Moriyama K, Tagami T, Akamizu T, Usui T, Saijo M, Kanamoto N, Hataya Y, Shimatsu A, Kuzuya H \& Nakao K. Thyroid hormone action is disrupted by bisphenol A as an antagonist. Journal of Clinical Endocrinology and Metabolism 200287 5185-5190. (https://doi. org/10.1210/jc.2002-020209)

49 Alonso-Magdalena P, Ropero AB, Soriano S, García-Arévalo M, Ripoll C, Fuentes E, Quesada I \& Nadal Á. Bisphenol-A acts as a potent estrogen via non-classical estrogen triggered pathways. Molecular and Cellular Endocrinology 2012355 201-207. (https://doi. org/10.1016/j.mce.2011.12.012)

50 Kitamura S, Jinno N, Ohta S, Kuroki H \& Fujimoto N. Thyroid hormonal activity of the flame retardants tetrabromobisphenol A and tetrachlorobisphenol A. Biochemical and Biophysical Research Communications 2002293 554-559. (https://doi.org/10.1016/S0006291X(02)00262-0)

51 Ikezuki Y, Tsutsumi O, Takai Y, Kamei Y \& Taketani Y. Determination of bisphenol A concentrations in human biological fluids reveals significant early prenatal exposure. Human Reproduction 200217 2839-2841. (https://doi.org/10.1093/humrep/17.11.2839)

52 Kitamura S, Suzuki T, Sanoh S, Kohta R, Jinno N, Sugihara K, Yoshihara S, Fujimoto N, Watanabe H \& Ohta S. Comparative study of the endocrine-disrupting activity of bisphenol A and 19 related compounds. Toxicological Sciences 200584 249-259. (https://doi. org/10.1093/toxsci/kfi074)

53 Freitas J, Cano P, Craig-Veit C, Goodson ML, Furlow JD \& Murk AJ. Detection of thyroid hormone receptor disruptors by a novel stable in vitro reporter gene assay. Toxicology in Vitro 201125 257-266. (https://doi.org/10.1016/j.tiv.2010.08.013)

54 Hofmann PJ, Schomburg L \& Köhrle J. Interference of endocrine disrupters with thyroid hormone receptor-dependent transactivation. Toxicological Sciences 2009110 125-137. (https://doi.org/10.1093/ toxsci/kfp086)

55 Goldinger DM, Demierre AL, Zoller O, Rupp H, Reinhard H, Magnin R, Becker TW \& Bourqui-Pittet M. Endocrine activity of alternatives to BPA found in thermal paper in Switzerland. Regulatory Toxicology and Pharmacology 201571 453-462. (https://doi. org/10.1016/j.yrtph.2015.01.002)

56 Geens T, Dirtu AC, Dirinck E, Malarvannan G, Van Gaal L, Jorens PG $\&$ Covaci A. Daily intake of bisphenol A and triclosan and their association with anthropometric data, thyroid hormones and weight loss in overweight and obese individuals. Environment International 201576 98-105. (https://doi.org/10.1016/j.envint.2014.12.003)

57 Sriphrapradang C, Chailurkit LO, Aekplakorn W \& Ongphiphadhanakul B. Association between bisphenol A and abnormal free thyroxine level in men. Endocrine 201344 441-447. (https://doi.org/10.1007/s12020-013-9889-y)

58 Wang F, Hua J, Chen M, Xia Y, Zhang Q, Zhao R, Zhou W, Zhang Z $\&$ Wang B. High urinary bisphenol A concentrations in workers and possible laboratory abnormalities. Occupational and Environmental
Medicine 201269 679-684. (https://doi.org/10.1136/oemed-2011100529)

59 Meeker JD \& Ferguson KK. Relationship between urinary phthalate and bisphenol a concentrations and serum thyroid measures in U.S. adults and adolescents from the national health and nutrition examination survey (NHANES) 2007-2008. Environmental Health Perspectives 2011119 1396-1402. (https://doi.org/10.1289/ ehp.1103582)

60 Aung MT, Johns LE, Ferguson KK, Mukherjee B, McElrath TF \& Meeker JD. Thyroid hormone parameters during pregnancy in relation to urinary bisphenol A concentrations: a repeated measures study. Environment International 2017 104 33-40. (https://doi. org/10.1016/j.envint.2017.04.001)

61 Romano ME, Webster GM, Vuong AM, Thomas Zoeller R, Chen A, Hoofnagle AN, Calafat AM, Karagas MR, Yolton K, Lanphear BP, et al. Gestational urinary bisphenol A and maternal and newborn thyroid hormone concentrations: the HOME Study. Environmental Research 2015138 453-460. (https://doi.org/10.1016/j.envres.2015.03.003)

62 Chevrier J, Gunier RB, Bradman A, Holland NT, Calafat AM, Eskenazi B \& Harley KG. Maternal urinary bisphenol a during pregnancy and maternal and neonatal thyroid function in the CHAMACOS study. Environmental Health Perspectives 2013121 138-144.

63 Minatoya M, Sasaki S, Araki A, Miyashita C, Itoh S, Yamamoto J, Matsumura T, Mitsui T, Moriya K, Cho K, et al. Cord blood bisphenol A levels and reproductive and thyroid hormone levels of neonates. Epidemiology 201728 S3-S9. (https://doi.org/10.1097/ EDE.0000000000000716)

64 Andrianou XD, Gängler S, Piciu A, Charisiadis P, Zira C, Aristidou K, Piciu D, Hauser R \& Makris KC. Human exposures to bisphenol A, bisphenol $\mathrm{F}$ and chlorinated bisphenol a derivatives and thyroid function. PLoS ONE 201611 e0155237. (https://doi.org/10.1371/ journal.pone.0155237)

65 Casas M, Forns J, Martínez D, Avella-García C, Valvi D, BallesterosGómez A, Luque N, Rubio S, Julvez J, Sunyer J, et al. Exposure to bisphenol A during pregnancy and child neuropsychological development in the INMA-Sabadell cohort. Environmental Research 2015142 671-679. (https://doi.org/10.1016/j. envres.2015.07.024)

66 Roen EL, Wang Y, Calafat AM, Wang S, Margolis A, Herbstman J, Hoepner LA, Rauh V \& Perera FP. Bisphenol A exposure and behavioral problems among inner city children at 7-9 years of age. Environmental Research 2015142 739-745. (https://doi.org/10.1016/j. envres.2015.01.014)

67 Harley KG, Gunier RB, Kogut K, Johnson C, Bradman A, Calafat AM \& Eskenazi B. Prenatal and early childhood bisphenol A concentrations and behavior in school-aged children. Environmental Research 2013126 43-50. (https://doi.org/10.1016/j. envres.2013.06.004)

68 Braun JM, Kalkbrenner AE, Calafat AM, Yolton K, Ye X, Dietrich KN \& Lanphear BP. Impact of early-life bisphenol a exposure on behavior and executive function in children. Pediatrics 2011128 873-882. (https://doi.org/10.1542/peds.2011-1335)

69 Braun JM, Yolton K, Dietrich KN, Hornung R, Ye X, Calafat AM \& Lanphear BP. Prenatal bisphenol A exposure and early childhood behavior. Environmental Health Perspectives 2009117 1945-1952. (https://doi.org/10.1289/ehp.0900979)

70 Evans SF, Kobrosly RW, Barrett ES, Thurston SW, Calafat AM, Weiss B, Stahlhut R, Yolton K \& Swan SH. Prenatal bisphenol A exposure and maternally reported behavior in boys and girls. Neurotoxicology 2014 45 91-99. (https://doi.org/10.1016/j.neuro.2014.10.003)

71 Tewar S, Auinger P, Braun JM, Lanphear B, Yolton K, Epstein JN, Ehrlich S \& Froehlich TE. Association of bisphenol A exposure and attention-deficit/hyperactivity disorder in a national sample of U.S. children. Environmental Research 2016150 112-118. (https://doi. org/10.1016/j.envres.2016.05.040) 
72 Perera F, Vishnevetsky J, Herbstman JB, Calafat AM, Xiong W, Rauh V \& Wang S. Prenatal bisphenol a exposure and child behavior in an innerity cohort. Environmental Health Perspectives 2012120 1190-1194. (https://doi.org/10.1289/ehp.1104492)

73 Arbuckle TE, Davis K, Boylan K, Fisher M \& Fu J. Bisphenol A, phthalates and lead and learning and behavioral problems in Canadian children 6-11 years of age: CHMS 2007-2009. Neurotoxicology 201654 89-98. (https://doi.org/10.1016/j. neuro.2016.03.014)

74 Diaz Weinstein S, Villafane JJ, Juliano N \& Bowman RE. Adolescent exposure to Bisphenol-A increases anxiety and sucrose preference but impairs spatial memory in rats independent of sex. Brain Research 2013 1529 56-65. (https://doi.org/10.1016/j.brainres.2013.07.018)

75 Bowman RE, Luine V, Diaz Weinstein S, Khandaker H, DeWolf S \& Frankfurt M. Bisphenol-A exposure during adolescence leads to enduring alterations in cognition and dendritic spine density in adult male and female rats. Hormones and Behavior 201569 89-97. (https://doi.org/10.1016/j.yhbeh.2014.12.007)

76 Xu X, Liu Y, Sadamatsu M, Tsutsumi S, Akaike M, Ushijima H \& Kato N. Perinatal bisphenol A affects the behavior and SRC-1 expression of male pups but does not influence on the thyroid hormone receptors and its responsive gene. Neuroscience Research 200758 149-155. (https://doi.org/10.1016/j.neures.2007.02.011)

77 Mizuo K, Narita M, Miyagawa K, Narita M, Okuno E \& Suzuki T. Prenatal and neonatal exposure to bisphenol-A affects the morphine-induced rewarding effect and hyperlocomotion in mice. Neuroscience Letters 2004356 95-98. (https://doi.org/10.1016/j. neulet.2003.11.027)

78 Kundakovic M, Gudsnuk K, Franks B, Madrid J, Miller RL, Perera FP \& Champagne FA. Sex-specific epigenetic disruption and behavioral changes following low-dose in utero bisphenol A exposure. PNAS 2013110 9956-9961. (https://doi.org/10.1073/pnas.1214056110)

79 Adriani W, Della Seta D, Dessi-Fulgheri F, Farabollini F \& Laviola G. Altered profiles of spontaneous novelty seeking, impulsive behavior and response to D-amphetamine in rats perinatally exposed to Bisphenol A. Environmental Health Perspectives 2003111 395-401. (https://doi.org/10.1289/ehp.5856)

80 Kumar D \& Kumar Thakur M. Perinatal exposure to bisphenol-A impairs spatial memory through upregulation of neurexin 1 and neuroligin3 expression in male mouse brain. PLOS ONE 20149 e110482.

81 Jašarević E, Williams SA, Vandas GM, Ellersieck MR, Liao C, Kannan K, Roberts RM, Geary DC \& Rosenfeld CS. Sex and dosedependent effects of developmental exposure to bisphenol A on anxiety and spatial learning in deer mice (Peromyscus maniculatus bairdii) offspring. Hormones and Behavior 201363 180-189. (https:// doi.org/10.1016/j.yhbeh.2012.09.009)

82 Kuwahara R, Kawaguchi S, Kohara Y, Cui H \& Yamashita K. Perinatal exposure to low-dose bisphenol A impairs spatial learning and memory in male rats. Journal of Pharmacological Sciences $2013 \mathbf{1 2 3}$ 132-139. (https://doi.org/10.1254/jphs.13093FP)

$83 \mathrm{Xu}$ X, Tian D, Hong X, Chen L \& Xie L. Sex-specific influence of exposure to bisphenol-A between adolescence and young adulthood on mouse behaviors. Neuropharmacology 201161 565-573. (https:// doi.org/10.1016/j.neuropharm.2011.04.027)

84 Poimenova A, Markaki E, Rahiotis C \& Kitraki E. Corticosteroneregulated actions in the rat brain are affected by perinatal exposure to low dose of bisphenol A. Neuroscience 2010167 741-749. (https:// doi.org/10.1016/j.neuroscience.2010.02.051)

85 Tian Y-H, Baek J-H, Lee S-Y \& Jang C-G. Prenatal and postnatal exposure to bisphenol a induces anxiolytic behaviors and cognitive deficits in mice. Synapse 201064 432-439. (https://doi.org/10.1002/ syn.20746)

86 Wolstenholme JT, Rissman EF \& Connelly JJ. The role of bisphenol A in shaping the brain, epigenome and behavior. Hormones and Behavior 201159 296-305. (https://doi.org/10.1016/j.

yhbeh.2010.10.001)

87 Jorgensen EM, Alderman MH \& Taylor HS. Preferential epigenetic programming of estrogen response after in utero xenoestrogen (bisphenol-A) exposure. FASEB Journal 201630 3194-3201. (https:// doi.org/10.1096/fj.201500089R)

88 Kyono Y, Subramani A, Ramadoss P, Hollenberg AN, Bonett RM \& Denver RJ. Liganded thyroid hormone receptors transactivate the DNA methyltransferase 3a gene in mouse neuronal cells. Endocrinology 2016157 3647-3657. (https://doi.org/10.1210/ en.2015-1529)

89 Kyono Y, Sachs LM, Bilesimo P, Wen L \& Denver RJ. Developmental and thyroid hormone regulation of the DNA methyltransferase 3a gene in xenopus tadpoles. Endocrinology 2016157 4961-4972. (https://doi.org/10.1210/en.2016-1465)

90 Government of Canada. Screening Assessment Report Phenol, 4,4'-(1-methylethylidene) bis[2,6-dibromo Ethanol, 2,2'-[(1-methylethylidene)bis[(2,6-dibromo-4,1-phenylene)oxy]]bis Benzene, 1,1'-(1-methylethylidene)bis[3,5-dibromo-4-(2-propenyloxy). Ottawa, Ontario, Canada: Environment Canada, 2013. (available at: http://publications.gc.ca/site/eng/455628/publication.html)

91 Government of Canada. Risk Management Scope for Phenol, 4,4'-(1-methylethylidene) bis[2,6-dibromo(Tetrabromobisphenol A). Chemical Abstract Service Registry Number (CAS RN): 79-94-7. Ottawa, Ontario, Canada: Environment Canada, 2012. (available at: http://www.ec.gc.ca/ese-ees/3BC8852B-124A-4D0D-83763A62D41530F8/TBBPA_RM\%20Scope_EN.pdf)

92 EFSA. Scientific Opinion on Tetrabromobisphenol A (TBBPA) and its derivatives in food. EFSA Journal 201192477 . (available at: https:// www.efsa.europa.eu/en/efsajournal/pub/2477)

93 Van der Ven LTM, Van de Kuil T, Verhoef A, Verwer CM, Lilienthal H, Leonards PE, Schauer UM, Cantón RF, Litens S, De Jong FH, et al. Endocrine effects of tetrabromobisphenol-A (TBBPA) in Wistar rats as tested in a one-generation reproduction study and a subacute toxicity study. Toxicology 2008245 76-89. (https://doi.org/10.1016/j. tox.2007.12.009)

94 Zieminska E, Ruszczynska A \& Lazarewicz JW. Tetrabromobisphenol A disturbs zinc homeostasis in cultured cerebellar granule cells: a dual role in neurotoxicity. Food and Chemical Toxicology 2017109 363-375. (https://doi.org/10.1016/j.fct.2017.09.021)

95 Zieminska E, Stafiej A, Toczylowska B, Albrecht J \& Lazarewicz JW. Role of ryanodine and NMDA receptors in tetrabromobisphenol A-induced calcium imbalance and cytotoxicity in primary cultures of rat cerebellar granule cells. Neurotoxicity Research 201528 195-208. (https://doi.org/10.1007/s12640-015-9546-8)

96 Zieminska E, Stafiej A, Toczylowska B \& Lazarewicz JW. Bastadin 12 and ryanodine reveal similarities between thapsigargin- and tetrabromobisphenol A-induced intracellular $\mathrm{Ca}(2+)$ release in cultured cerebellar granule cells. Journal of Physiology and Pharmacology 201465 679-686.

97 Zieminska E, Lenart J, Diamandakis D \& Lazarewicz JW. The role of $\mathrm{Ca} 2+$ imbalance in the induction of acute oxidative stress and cytotoxicity in cultured rat cerebellar granule cells challenged with tetrabromobisphenol A. Neurochemical Research 201642 1-11. (https://doi.org/10.1007/s11064-016-2075-x)

98 Hendriks HS, Van kleef RGDM, Van den berg M \& Westerink RHS. Multiple novel modes of action involved in the in vitro neurotoxic effects of tetrabromobisphenol-A. Toxicological Sciences 2012128 235-246. (https://doi.org/10.1093/toxsci/kfs136)

99 Cope RB, Kacew S \& Dourson M. A reproductive, developmental and neurobehavioral study following oral exposure of tetrabromobisphenol A on Sprague-Dawley rats. Toxicology 2015329 49-59. (https://doi.org/10.1016/j.tox.2014.12.013)

100 Colnot T, Kacew S \& Dekant W. Mammalian toxicology and human exposures to the flame retardant 2,2',6,6'-tetrabromo-4, $4^{\prime}$ - http://www.endocrineconnections.org

https://doi.org/10.1530/EC-18-0029
() 2018 The authors Published by Bioscientifica Ltd
This work is licensed under a Creative Commons Attribution-NonCommercial-NoDerivatives 4.0 International License. 
isopropylidenediphenol (TBBPA): Implications for risk assessment. Archives of Toxicology $2014 \mathbf{8 8} 553-573$.

101 VibergH \& Eriksson P. Differences in neonatal neurotoxicity of brominated flame retardants, PBDE 99 and TBBPA, in mice. Toxicology 2011289 59-65. (https://doi.org/10.1016/j.tox.2011.07.010)

102 Decherf S, Seugnet I, Fini JB, Clerget-Froidevaux MS \& Demeneix BA. Disruption of thyroid hormone-dependent hypothalamic set-points by environmental contaminants. Molecular and Cellular Endocrinology 2010323 172-182. (https://doi.org/10.1016/j.mce.2010.04.010)

103 Chen J, Tanguay RL, Xiao Y, Haggard DE, Ge X, Jia Y, Zheng Y, Dong $Q$, Huang C \& Lin K. TBBPA exposure during a sensitive developmental window produces neurobehavioral changes in larval zebrafish. Environmental Pollution 2016216 53-63. (https://doi. org/10.1016/j.envpol.2016.05.059)

104 Nakajima A, Saigusa D, Tetsu N, Yamakuni T, Tomioka Y \& Hishinuma T. Neurobehavioral effects of tetrabromobisphenol A, a brominated flame retardant, in mice. Toxicology Letters 2009189 78-83. (https://doi.org/10.1016/j.toxlet.2009.05.003)

105 Lilienthal H, Verwer CM, van der Ven LTM, Piersma AH \& Vos JG. Exposure to tetrabromobisphenol A (TBBPA) in Wistar rats: neurobehavioral effects in offspring from a one-generation reproduction study. Toxicology 2008246 45-54. (https://doi. org/10.1016/j.tox.2008.01.007)

$106 \mathrm{Ng}$ L, Kelley MW \& Forrest D. Making sense with thyroid hormonethe role of T 3 in auditory development. Nature Reviews Endocrinology 20139 296-307. (https://doi.org/10.1038/nrendo.2013.58)

107 National Toxicology Program. NTP technical report on the toxicology studies of tetrabromobisphenol A (CAS NO. 79-94-7) in F344/NTac rats and $\mathrm{B} 6 \mathrm{C} 3 \mathrm{~F} 1 / \mathrm{N}$ mice and toxicology and carcinogenesis study of tetrabromobisphenol A in Wistar Han (Crl:WI(Han)) rats and B6C3F1/N mice (gavage studies). Research Triangle Park, NC: USA: National Toxicology Program, 2014. (available at: https://ntp.niehs. nih.gov/ntp/htdocs/lt_rpts/tr587_508.pdf)

108 Lai DY, Kacew S \& Dekant W. Tetrabromobisphenol A (TBBPA): possible modes of action of toxicity and carcinogenicity in rodents. Food and Chemical Toxicology 201580 206-214. (https://doi. org/10.1016/j.fct.2015.03.023)

109 Hamers T, Kamstra JH, Sonneveld E, Murk AJ, Kester MH, Andersson PL, Legler J \& Brouwer A. In vitro profiling of the endocrine-disrupting potency of brominated flame retardants. Toxicological Sciences 200692 157-173. (https://doi.org/10.1093/ toxsci/kfj187)

110 Lévy-Bimbot M, Major G, Courilleau D, Blondeau JP \& Lévi Y. Tetrabromobisphenol-A disrupts thyroid hormone receptor alpha function in vitro: use of fluorescence polarization to assay corepressor and coactivator peptide binding. Chemosphere $2012 \mathbf{8 7}$ 782-788. (https://doi.org/10.1016/j.chemosphere.2011.12.080)

111 Kitamura S, Kato T, Iida M, Jinno N, Suzuki T, Ohta S, Fujimoto N, Hanada H, Kashiwagi K \& Kashiwagi A. Anti-thyroid hormonal activity of tetrabromobisphenol A, a flame retardant, and related compounds: affinity to the mammalian thyroid hormone receptor, and effect on tadpole metamorphosis. Life Science $2005 \mathbf{7 6}$ 1589-1601. (https://doi.org/10.1016/j.lfs.2004.08.030)

112 Zhang YF, Xu W, Lou QQ, Li YY, Zhao YX, Wei WJ, Qin ZF, Wang HL $\&$ Li JZ. Tetrabromobisphenol a disrupts vertebrate development via thyroid hormone signaling pathway in a developmental stagedependent manner. Environmental Science and Technology 201448 8227-8234. (https://doi.org/10.1021/es502366g)

113 Wang Y, Li Y, Qin Z \& Wei W. Re-evaluation of thyroid hormone signaling antagonism of tetrabromobisphenol A for validating the T3-induced Xenopus metamorphosis assay. Journal of Environmental Sciences 201752 325-332. (https://doi.org/10.1016/j.jes.2016.09.021)

114 Fini JB, Le Mével S, Palmier K, Darras VM, Punzon I, Richardson SJ, Clerget-Froidevaux MS \& Demeneix BA. Thyroid hormone signaling in the Xenopus laevis embryo is functional and susceptible to endocrine disruption. Endocrinology 2012153 5068-5081. (https:// doi.org/10.1210/en.2012-1463)

115 Mengeling BJ, Wei Y, Dobrawa LN, Streekstra M, Louisse J, Singh V4, Singh L, Lein PJ, Wulff H, Murk AJ \& Furlow JD. A multi-tiered, in vivo, quantitative assay suite for environmental disruptors of thyroid hormone signaling. Aquatic Toxicology 2017190 1-10. (https://doi. org/10.1016/j.aquatox.2017.06.019)

116 Borghoff SJ, Wikoff D, Harvey S \& Haws L. Dose- and timedependent changes in tissue levels of tetrabromobisphenol A (TBBPA) and its sulfate and glucuronide conjugates following repeated administration to female Wistar Han Rats. Toxicology Reports 20163 190-201. (https://doi.org/10.1016/j.toxrep.2016.01.007)

117 Yueh M-F \& Tukey RH. Triclosan: a widespread environmental toxicant with many biological effects. Annual Review of Pharmacology and Toxicology 201656 251-272. (https://doi.org/10.1146/annurevpharmtox-010715-103417)

118 Calafat AM, Ye X, Wong LY, Reidy JA \& Needham LL. Urinary concentrations of triclosan in the U.S. population: 2003-2004. Environmental Health Perspectives 2008116 303-307. (https://doi. org/10.1289/ehp.10768)

119 Chapin RE, Adams J, Boekelheide K, Gray LE Jr, Hayward SW, Lees PS, McIntyre BS, Portier KM, Schnorr TM, Selevan SG, et al. NTP-CERHR expert panel report on the reproductive and developmental toxicity of bisphenol A. Birth Defects Research Part B: Developmental and Reproductive Toxicology 200883 157-395. (https://doi.org/10.1002/ bdrb.20147)

120 Dayan AD. Risk assessment of triclosan (Irgasan) in human breast milk. Food and Chemical Toxicology 200745 125-129. (https://doi. org/10.1016/j.fct.2006.08.009)

121 Arbuckle TE, Marro L, Davis K, Fisher M, Ayotte P, Bélanger P, Dumas P, LeBlanc A, Bérubé R, Gaudreau É, et al. Exposure to free and conjugated forms of bisphenol a and triclosan among pregnant women in the MIREC cohort. Environmental Health Perspectives 2015 123 277-284. (https://doi.org/10.1289/ehp.1408187)

122 Philippat C, Wolff MS, Calafat AM, Ye X, Bausell R, Meadows M, Stone J, Slama R \& Engel SM. Prenatal exposure to environmental phenols: concentrations in amniotic fluid and variability in urinary concentrations during pregnancy. Environmental Health Perspectives 2013121 1225-1231. (https://doi.org/10.1289/ehp.1206335)

123 EU Commission. COMMISSION REGULATION (EU) No 358/2014 of 9 April 2014 amending Annexes II and V to Regulation (EC) No 1223/2009 of the European Parliament and of the Council on cosmetic products. Official Journal of the European Union, 2014. (available at: http://data.europa.eu/eli/reg/2014/358/oj)

124 Chen L, Wang Z, Jing Z, Wang Z, Cao S \& Yu T. Accumulation and risk of triclosan in surface sediments near the outfalls of municipal wastewater treatment plants. Bulletin of Environmental Contamination and Toxicology 201595 525-529. (https://doi.org/10.1007/s00128015-1630-5)

125 Díaz-Cruz MS \& Barceló D. Personal Care Products in the Aquatic Environment. The Handbook of Environmental Chemistry, series volume 36. New York, NY, USA: Springer International Publishing, 2015. (https://doi.org/10.1007/978-3-319-18809-6)

126 Axelstad M, Boberg J, Vinggaard AM, Christiansen S \& Hass U. Triclosan exposure reduces thyroxine levels in pregnant and lactating rat dams and in directly exposed offspring. Food and Chemical Toxicology 201359 534-540. (https://doi.org/10.1016/j. fct.2013.06.050)

127 Paul KB, Hedge JM, Bansal R, Zoeller RT, Peter R, DeVito MJ \& Crofton KM. Developmental triclosan exposure decreases maternal, fetal, and early neonatal thyroxine: a dynamic and kinetic evaluation of a putative mode-of-action. Toxicology 2012300 31-45. (https:// doi.org/10.1016/j.tox.2012.05.023)

128 Rodríguez PE \& Sanchez MS. Maternal exposure to triclosan impairs thyroid homeostasis and female pubertal development in Wistar rat http://www.endocrineconnections.org

https://doi.org/10.1530/EC-18-0029 (c) 2018 The authors

Published by Bioscientifica Ltd
This work is licensed under a Creative Commons Attribution-NonCommercial-NoDerivatives 4.0 International License. 
offspring. Journal of Toxicology and Environmental Health, Part A 2010 73 1678-1688.

129 Crofton KM, Paul KB, DeVito MJ \& Hedge JM. Short-term in vivo exposure to the water contaminant triclosan: evidence for disruption of thyroxine. Environmental Toxicology and Pharmacology 200724 194-197. (https://doi.org/10.1016/j.etap.2007.04.008)

130 Paul KB, Thompson JT, Simmons SO, Vanden Heuvel JP \& Crofton KM. Evidence for triclosan-induced activation of human and rodent xenobiotic nuclear receptors. Toxicology In Vitro 201327 2049-2060. (https://doi.org/10.1016/j.tiv.2013.07.008)

131 Zorrilla LM, Gibson EK, Jeffay SC, Crofton KM, Setzer WR, Cooper RL $\&$ Stoker TE. The effects of triclosan on puberty and thyroid hormones in male wistar rats. Toxicological Sciences 2009107 56-64. (https://doi.org/10.1093/toxsci/kfn225)

132 Veldhoen N, Skirrow RC, Osachoff H, Wigmore H, Clapson DJ, Gunderson MP, Van Aggelen G \& Helbing CC. Corrigendum to 'The bactericidal agent triclosan modulates thyroid hormone-associated gene expression and disrupts postembryonic anuran development'. Aquatic Toxicology 200783 84. (https://doi.org/10.1016/j. aquatox.2006.08.010)

133 Fort DJ, Mathis MB, Hanson W, Fort CE, Navarro LT, Peter R, Büche C, Unger S, Pawlowski S \& Plautz JR. Triclosan and thyroidmediated metamorphosis in anurans: differentiating growth effects from thyroid-driven metamorphosis in Xenopus laevis. Toxicological Sciences 2011121 292-302. (https://doi.org/10.1093/toxsci/kfr069)

134 Regnault C, Willison J, Veyrenc S, Airieau A, Méresse P, Fortier M, Fournier M, Brousseau P, Raveton M \& Reynaud S. Metabolic and immune impairments induced by the endocrine disruptors benzo[a] pyrene and triclosan in Xenopus tropicalis. Chemosphere 2016155 519-527. (https://doi.org/10.1016/j.chemosphere.2016.04.047)

135 Lan Z, Kim TH, Bi KS, Chen XH \& Kim HS. Triclosan exhibits a tendency to accumulate in the epididymis and shows sperm toxicity in male sprague-dawley rats. Environmental Toxicology 201530 83-91. (https://doi.org/10.1002/tox.21897)

136 Stoker TE, Gibson EK \& Zorrilla LM. Triclosan exposure modulates estrogen-dependent responses in the female wistar rat. Toxicological Sciences 2010117 45-53. (https://doi.org/10.1093/toxsci/kfq180)

137 Huang H, Du G, Zhang W, Hu J, Wu D, Song L, Xia Y \& Wang X. The in vitro estrogenic activities of triclosan and triclocarban. Journal of Applied Toxicology 201434 1060-1067. (https://doi.org/10.1002/ jat.3012)

138 Henry ND \& Fair PA. Comparison of in vitro cytotoxicity, estrogenicity and anti-estrogenicity of triclosan, perfluorooctane sulfonate and perfluorooctanoic acid. Journal of Applied Toxicology 201333 265-272. (https://doi.org/10.1002/jat.1736)

139 Gee RH, Charles A, Taylor N \& Darbre PD. Oestrogenic and androgenic activity of triclosan in breast cancer cells. Journal of Applied Toxicology 200828 78-91. (https://doi.org/10.1002/jat.1316)

140 Kim JY, Yi BR, Go RE, Hwang KA, Nam KH \& Choi KC. Methoxychlor and triclosan stimulates ovarian cancer growth by regulating cell cycle- and apoptosis-related genes via an estrogen receptordependent pathway. Environmental Toxicology and Pharmacology 2014 37 1264-1274. (https://doi.org/10.1016/j.etap.2014.04.013)

141 Lee HR, Hwang KA, Nam KH, Kim HC \& Choi KC. Progression of breast cancer cells was enhanced by endocrine-disrupting chemicals, triclosan and octylphenol, via an estrogen receptor-dependent signaling pathway in cellular and mouse xenograft models. Chemical Research in Toxicology 201427 834-842. (https://doi.org/10.1021/ tx5000156)

142 Louis GW, Hallinger DR \& Stoker TE. The effect of triclosan on the uterotrophic response to extended doses of ethinyl estradiol in the weanling rat. Reproductive Toxicology 201336 71-77. (https://doi org/10.1016/j.reprotox.2012.12.001)

143 Pollock T, Greville LJ, Tang B \& deCatanzaro D. Triclosan elevates estradiol levels in serum and tissues of cycling and peri-implantation female mice. Reproductive Toxicology 201665 394-401. (https://doi. org/10.1016/j.reprotox.2016.09.004)

144 James MO, Li W, Summerlot DP, Rowland-Faux L \& Wood CE. Triclosan is a potent inhibitor of estradiol and estrone sulfonation in sheep placenta. Environment International 201036 942-949. (https:// doi.org/10.1016/j.envint.2009.02.004)

145 Wang LQ, Falany CN \& James MO. Triclosan as a substrate and inhibitor of 3'-phosphoadenosine 5'-phosphosulfate-sulfotransferase and UDP-glucuronosyl transferase in human liver fractions. Drug Metabolism and Disposition 200432 1162-1169. (https://doi. org/10.1124/dmd.104.000273)

146 Aker AM, Watkins DJ, Johns LE, Ferguson KK, Soldin OP, Anzalota Del Toro LV, Alshawabkeh AN, Cordero JF \& Meeker JD. Phenols and parabens in relation to reproductive and thyroid hormones in pregnant women. Environmental Research 2016151 30-37. (https:// doi.org/10.1016/j.envres.2016.07.002)

147 Allmyr M, Panagiotidis G, Sparve E, Diczfalusy U \& SandborghEnglund G. Human exposure to triclosan via toothpaste does not change cyp3a4 activity or plasma concentrations of thyroid hormones. Basic and Clinical Pharmacology and Toxicology 2009105 339-344. (https://doi.org/10.1111/j.1742-7843.2009.00455.x)

148 Cullinan MP, Palmer JE, Carle AD, West MJ \& Seymour GJ. Long term use of triclosan toothpaste and thyroid function. Science of the Total Environment 2012416 75-79. (https://doi.org/10.1016/j. scitotenv.2011.11.063)

149 Koeppe ES, Ferguson KK, Colacino JA \& Meeker JD. Relationship between urinary triclosan and paraben concentrations and serum thyroid measures in NHANES 2007-2008. Science of the Total Environment 2013 445-446 299-305.

150 Poole AC, Pischel L, Ley C, Suh G, Goodrich JK, Haggerty TD, Ley RE \& Parsonnet J. Crossover control study of the effect of personal care products containing triclosan on the microbiome. mSphere 20161 e00056-15. (https://doi.org/10.1128/mSphere.00056-15)

151 Wang X, Ouyang F, Feng L, Wang X, Liu Z \& Zhang J. Maternal urinary triclosan concentration in relation to maternal and neonatal thyroid hormone levels: a prospective study. Environmental Health Perspectives 2013125 67017. (https://doi.org/10.1289/EHP500)

152 Lassen TH, Frederiksen H, Kyhl HB, Swan SH, Main KM, Andersson AM, Lind DV, Husby S, Wohlfahrt-Veje C, Skakkebæk NE, et al. Prenatal triclosan exposure and anthropometric measures including anogenital distance in Danish infants. Environmental Health Perspectives 2016124 1261-1268. (https://doi.org/10.1289/ ehp.1409637)

153 Johannes J Jayarama-Naidu R, Meyer F, Wirth EK, Schweizer U, Schomburg L, Köhrle J \& Renko K. Silychristin, a flavonolignan derived from the milk thistle, is a potent inhibitor of the thyroid hormone transporter MCT8. Endocrinology 2016157 1694-701. (https://doi.org/10.1210/en.2015-1933)

154 Hossard L, Philibert A, Bertrand M, Colnenne-David C, Debaeke P, Munier-Jolain N, Jeuffroy MH, Richard G \& Makowski D. Effects of halving pesticide use on wheat production. Scientific Reports 20144 4405. (https://doi.org/10.1038/srep04405)

155 EFSA. Scientific opinion on the identification of pesticides to be included in cumulative assessment groups on the basis of their toxicological profile. EFSA Journal 201311 3293. (https://doi. org/10.2903/j.efsa.2013.3293)

156 Carson R. Silent spring. Foreign Affairs 196276 218-219.

157 Guimarães RM, Asmus CIRF \& Meyer A. DDT reintroduction for malaria control: the cost-benefit debate for public health. Cadernos de Saúde Pública 200723 2835-2844.

158 Hernández-Mariano JÁ, Torres-Sánchez L, Bassol-Mayagoitia S, Escamilla-Nuñez MC, Cebrian ME, Villeda-Gutiérrez ÉA, LópezRodríguez G, Félix-Arellano EE \& Blanco-Muñoz J. Effect of exposure to $\mathrm{p}, \mathrm{p}^{\prime}$-DDE during the first half of pregnancy in the maternal thyroid profile of female residents in a Mexican floriculture area. http://www.endocrineconnections.org https://doi.org/10.1530/EC-18-0029
() 2018 The authors Published by Bioscientifica Ltd
This work is licensed under a Creative Commons Attribution-NonCommercial-NoDerivatives 4.0 International License. 
Environmental Research 2017156 597-604. (https://doi.org/10.1016/j. envres.2017.04.013)

159 Barraza-Vázquez A, Borja-Aburto VH, Bassol-Mayagoitia S, Monrroy A \& Recio-Vega R. Dichlorodiphenyldichloroethylene concentrations in umbilical cord of newborns and determinant maternal factors. Journal of Applied Toxicology 200828 27-34. (https://doi.org/10.1002/ jat.1247)

160 Sala M, Ribas-Fitó N, Cardo E, de Muga ME, Marco E, Mazón C, Verdú A, Grimalt JO \& Sunyer J. Levels of hexachlorobenzene and other organochlorine compounds in cord blood: exposure across placenta. Chemosphere 200143 895-901. (https://doi.org/10.1016/ S0045-6535(00)00450-1)

161 Cano-Sancho G, Salmon AG \& La Merrill MA. Association between exposure to $\mathrm{p}, \mathrm{p}^{\prime}$-DDT and its metabolite $\mathrm{p}, \mathrm{p}^{\prime}$-DDE with obesity: integrated systematic review and meta-analysis. Environmental Health Perspectives 2017125 96002. (https://doi.org/10.1289/EHP527)

162 Gaspar FW, Harley KG, Kogut K, Chevrier J, Mora AM, Sjödin A \& Eskenazi B. Prenatal DDT and DDE exposure and child IQ in the CHAMACOS cohort. Environment International 201585 206-212. (https://doi.org/10.1016/j.envint.2015.09.004)

163 Zhang X, Wu X, Lei B, Jing Y, Jiang Z, Zhang X, Fang X \& Yu Y. Transplacental transfer characteristics of organochlorine pesticides in paired maternal and cord sera, and placentas and possible influencing factors. Environmental Pollution 2018233 446-454. (https://doi.org/10.1016/j.envpol.2017.10.075)

164 Forns J, Mandal S, Iszatt N, Polder A, Thomsen C, Lyche JL, Stigum H, Vermeulen R \& Eggesbø M. Novel application of statistical methods for analysis of multiple toxicants identifies DDT as a risk factor for early child behavioral problems. Environmental Research 2016 151 91-100. (https://doi.org/10.1016/j.envres.2016.07.014)

165 Kezios KL Liu X, Cirillo PM, Cohn BA, Kalantzi OI,

Wang Y, Petreas MX, Park JS \& Factor-Litvak P.

Dichlorodiphenyltrichloroethane (DDT), DDT metabolites and pregnancy outcomes. Reproductive Toxicology 201335 156-164. (https://doi.org/10.1016/j.reprotox.2012.10.013)

166 Torres-Sánchez L, Schnaas L, Rothenberg SJ, Cebrián ME, OsorioValencia E, Hernández Mdel C, García-Hernández RM \& LópezCarrillo L. Prenatal p,ṕ-DDE exposure and neurodevelopment among children 3.5-5 years of age. Environmental Health Perspectives 2013 121 263-268.

167 Eskenazi B, Chevrier J, Rosas LG, Anderson HA, Bornman MS, Bouwman H, Chen A, Cohn BA, de Jager C, Henshel DS, et al. The pine river statement: human health consequences of DDT use. Environmental Health Perspectives 2009117 1359-1367. (https://doi. org/10.1289/ehp.11748)

168 Torres-Sánchez L, Rothenberg SJ, Schnaas L, Cebrián ME, Osorio E, Del Carmen Hernández M, García-Hernández RM, Del Rio-Garcia C, Wolff MS \& López-Carrillo L. In utero p,p'-DDE exposure and infant neurodevelopment: a perinatal cohort in Mexico. Environmental Health Perspectives 2007115 435-439. (https://doi.org/10.1289/ ehp.9566)

169 Eskenazi B, Marks AR, Bradman A, Fenster L, Johnson C, Barr DB \& Jewell NP. In utero exposure to dichlorodiphenyltrichloroethane (DDT) and dichlorodiphenyldichloroethylene (DDE) and neurodevelopment among young Mexican American children. Pediatrics 2006118 233-241. (https://doi.org/10.1542/peds.20053117)

170 Ribas-Fitó N, Torrent M, Carrizo D, Muñoz-Ortiz L, Júlvez J, Grimalt JO \& Sunyer J. In utero exposure to background concentrations of DDT and cognitive functioning among preschoolers. American Journal of Epidemiology 2006164 955-962. (https://doi.org/10.1093/aje/kwj299)

171 Zhuang S, Zhang J, Wen Y, Zhang C \& Liu W. Distinct mechanisms of endocrine disruption of DDT-related pesticides toward estrogen receptor $\alpha$ and estrogen-related receptor $\gamma$. Environmental Toxicology and Chemistry 201231 2597-2605. (https://doi.org/10.1002/etc.1986)
172 Mussi P, Ciana P, Raviscioni M, Villa R, Regondi S, Agradi E, Maggi A \& Di Lorenzo D. Activation of brain estrogen receptors in mice lactating from mothers exposed to DDT. Brain Research Bulletin 2005 65 241-247. (https://doi.org/10.1016/j.brainresbull.2004.11.016)

173 Kojima H, Katsura E, Takeuchi S, Niiyama K \& Kobayashi K. Screening for estrogen and androgen receptor activities in 200 pesticides by in vitro reporter gene assays using Chinese hamster ovary cells. Environmental Health Perspectives 2004112 524-531. (https://doi.org/10.1289/ehp.6649)

174 Kelce WR, Stone CR, Laws SC, Gray LE, Kemppainen JA \& Wilson EM. Persistent DDT Metabolite p,p'-DDE is a potent androgen receptor antagonist. Obstetrical and Gynecological Survey 199651 111-114. (https://doi.org/10.1038/375581a0)

175 Schell LM, Gallo MV, Deane GD, Nelder KR, DeCaprio AP, Jacobs A \& Akwesasne Task Force on the Environment. Relationships of polychlorinated biphenyls and dichlorodiphenyldichloroethylene (p,p'-DDE) with testosterone levels in adolescent males. Environmental Health Perspectives 2014122 304-309. (https://doi. org/10.1289/ehp.122-A304)

176 Eskenazi B, Rauch SA, Tenerelli R, Huen K, Holland NT, Lustig RH, Kogut K, Bradman A, Sjödin A \& Harley KG. In utero and childhood DDT, DDE, PBDE and PCBs exposure and sex hormones in adolescent boys: the CHAMACOS study. International Journal of Hygiene and Environmental Health 2017220 364-372. (https://doi.org/10.1016/j. ijheh.2016.11.001)

177 Cohn BA, La Merrill M, Krigbaum NY, Yeh G, Park JS, Zimmermann L $\&$ Cirillo PM. DDT exposure in utero and breast cancer. Journal of Clinical Endocrinology and Metabolism 2015100 2865-2872. (https:// doi.org/10.1210/jc.2015-1841)

178 de Cock M, de Boer MR, Lamoree M, Legler J \& van de Bor M. Prenatal exposure to endocrine disrupting chemicals in relation to thyroid hormone levels in infants - a Dutch prospective cohort study. Environmental Health 201413 106. (https://doi. org/10.1186/1476-069X-13-106)

179 Blanco-Muñoz J, Lacasaña M, López-Flores I, Rodríguez-Barranco M, González-Alzaga B, Bassol S, Cebrian ME, López-Carrillo L \& AguilarGarduño C. Association between organochlorine pesticide exposure and thyroid hormones in floriculture workers. Environmental Research 2016150 357-363. (https://doi.org/10.1016/j.envres.2016.05.054)

180 Li C, Cheng Y, Tang Q, Lin S, Li Y, Hu X, Nian J, Gu H, Lu Y, Tang H, et al. The association between prenatal exposure to organochlorine pesticides and thyroid hormone levels in newborns in Yancheng, China. Environmental Research 2014129 47-51. (https://doi. org/10.1016/j.envres.2013.12.009)

181 Parent AS, Naveau E, Gerard A, Bourguignon JP \& Westbrook GL. Early developmental actions of endocrine disruptors on the hypothalamus, hippocampus, and cerebral cortex. Journal of Toxicology and Environmental Health: Part B, Critical Reviews 201114 328-345. (https://doi.org/10.1080/10937404.2011.578556)

182 Takser L, Mergler D, Baldwin M, de Grosbois S, Smargiassi A $\&$ Lafond J. Thyroid hormones in pregnancy in relation to environmental exposure to organochlorine compounds and mercury. Environmental Health Perspectives 2005113 1039-1045. (https://doi. org/10.1289/ehp.7685)

183 Lopez-Espinosa MJ, Vizcaino E, Murcia M, Llop S, Espada M, Seco V, Marco A, Rebagliato M, Grimalt JO \& Ballester F. Association between thyroid hormone levels and 4,4'-DDE concentrations in pregnant women (Valencia, Spain). Environmental Research 2009109 479-485. (https://doi.org/10.1016/j.envres.2009.02.003)

184 Rossi M, Taddei AR, Fasciani I, Maggio R \& Giorgi F. The cell biology of the thyroid-disrupting mechanism of dichlorodiphenyltrichloroethane (DDT). Journal of Endocrinological Investigation 201741 67-73. (https://doi.org/10.1007/s40618-0170716-9)

185 Rossi M, Dimida A, Dell'anno MT, Trincavelli ML, Agretti P, Giorgi F, Corsini GU, Pinchera A, Vitti P, Tonacchera M, et al. The thyroid

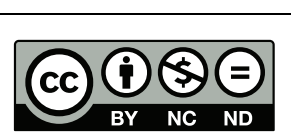

This work is licensed under a Creative Commons Attribution-NonCommercial-NoDerivatives 4.0 International License. 
disruptor 1,1,1-trichloro-2,2-bis(p-chlorophenyl)-ethane appears to be an uncompetitive inverse agonist for the thyrotropin receptor. Journal of Pharmacology and Experimental Therapeutics $2007 \mathbf{3 2 0}$ 465-474. (https://doi.org/10.1124/jpet.106.113613)

186 Rossi M, Dimida A, Ferrarini E, Silvano E, De Marco G, Agretti P, Aloisi G, Simoncini T, Di Bari L, Tonacchera M, et al. Presence of a putative steroidal allosteric site on glycoprotein hormone receptors. European Journal of Pharmacology 2009623 155-159. (https://doi. org/10.1016/j.ejphar.2009.09.029)

187 Santini F, Vitti P, Ceccarini G, Mammoli C, Rosellini V, Pelosini C, Marsili A, Tonacchera M, Agretti P, Santoni T, et al. In vitro assay of thyroid disruptors affecting TSH-stimulated adenylate cyclase activity. Journal of Endocrinological Investigation 200326 950-955. (https://doi.org/10.1007/BF03348190)

188 De Gregorio F, Pellegrino M, Picchietti S, Belardinelli MC, Taddei AR, Fausto AM, Rossi M, Maggio R \& Giorgi F. The insecticide 1,1,1-trichloro-2,2-bis(p-chlorophenyl) ethane (DDT) alters the membrane raft location of the TSH receptor stably expressed in Chinese hamster ovary cells. Toxicology and Applied Pharmacology 2011253 121-129. (https://doi.org/10.1016/j.taap.2011.03.018)

189 Liu C, Shi Y, Li H, Wang Y \& Yang KP. p-DDE disturbs the homeostasis of thyroid hormones via thyroid hormone receptors, transthyretin, and hepatic enzymes. Hormone and Metabolic Research 201143 391-396. (https://doi.org/10.1055/s-0031-1277135)

190 Liu C, Ha M, Li L \& Yang K. PCB153 and p,p'-DDE disorder thyroid hormones via thyroglobulin, deiodinase 2 , transthyretin, hepatic enzymes and receptors. Environmental Science and Pollution Research 201421 11361-11369. (https://doi.org/10.1007/s11356-014-3093-3)

191 Yaglova NV \& Yaglov VV. Changes in thyroid status of rats after prolonged exposure to low dose dichlorodiphenyltrichloroethane. Bulletin of Experimental Biology and Medicine 2014156 760-762. (https://doi.org/10.1007/s10517-014-2443-y)

192 Gocmen A, Peters HA, Cripps DJ, Bryan GT \& Morris CR. Hexachlorobenzene episode in Turkey. Biomedical and Environmental Sciences 19892 36-43.

193 Schmid R. Cutaneous porphyria in Turkey. New England Journal of Medicine 1960263 397-398. (https://doi.org/10.1056/ NEJM196008252630807)

194 Chalouati H, Gamet-Payrastre L \& Ben Saad M. Irreversible thyroid disruption induced after subchronic exposure to hexachlorobenzene in male rats. Toxicology and Industrial Health 201332 822-831. (https://doi.org/10.1177/0748233713511511)

195 Cabral JR \& Shubik P. Carcinogenic activity of hexachlorobenzene in mice and hamsters. IARC Scientific Publications 1986 411-416. (https://doi.org/10.1038/269510a0)

196 Cabral JRP, Mollner T, Raitano F \& Shubik P. Carcinogenesis of hexachlorobenzene in mice. International Journal of Cancer 197923 47-51. (https://doi.org/10.1002/ijc.2910230110)

197 Cabral JRP, Shubik P, Mollner T \& Raitano F. Carcinogenic activity of hexacholorobenzene in hamsters. Nature 1977269 510-511. (https:// doi.org/10.1038/269510a0)

198 Can C \& Nigogosyan G. Acquired toxic porphyria cutanea tarda due to hexachlorobenzene. Report of 348 cases caused by this fungicide. JAMA 1963183 88-91.

199 Eskenazi B, Harley K, Bradman A, Weltzien E, Jewell NP, Barr DB, Furlong CE \& Holland NT. Association of in utero organophosphate pesticide exposure and fetal growth and length of gestation in an agricultural population. Environmental Health Perspectives 2004112 1116-1124. (https://doi.org/10.1289/ehp.6789)

200 Ribas-Fitó N, Torrent M, Carrizo D, Júlvez J, Grimalt JO \& Sunyer J. Exposure to hexachlorobenzene during pregnancy and children's social behavior at 4 years of age. Environmental Health Perspectives 2007115 447-450. (https://doi.org/10.1289/ehp.9314)

201 Smink A, Ribas-Fito N, Garcia R, Torrent M, Mendez MA, Grimalt JO \& Sunyer J. Exposure to hexachlorobenzene during pregnancy increases the risk of overweight in children aged 6 years. Acta
Paediatrica 200897 1465-1469. (https://doi.org/10.1111/j.16512227.2008.00937.x)

202 Sala M, Sunyer J, Herrero C, To-Figueras J \& Grimalt J. Association between serum concentrations of hexachlorobenzene and polychlorobiphenyls with thyroid hormone and liver enzymes in a sample of the general population. Occupational and Environmental Medicine 200158 172-177. (https://doi.org/10.1136/oem.58.3.172)

203 Meeker JD, Altshul L \& Hauser R. Serum PCBs, p,p'-DDE and HCB predict thyroid hormone levels in men. Environmental Research 2007 104 296-304. (https://doi.org/10.1016/j.envres.2006.11.007)

204 Foster WG, McMahon A, Villeneuve DC \& Jarrell JF. Hexachlorobenzene (HCB) suppresses circulating progesterone concentrations during the luteal phase in the cynomolgus monkey. Journal of Applied Toxicology 199212 13-17. (https://doi.org/10.1002/ jat.2550120105)

205 Foster WG, McMahon A, Younglai EV, Jarrell JF \& Lecavalier P. Alterations in circulating ovarian steroids in hexachlorobenzeneexposed monkeys. Reproductive Toxicology 19959 541-548. (https:// doi.org/10.1016/0890-6238(95)02004-7)

206 Jarrell JF, McMahon A, Villeneuve D, Franklin C, Singh A, Valli VE $\&$ Bartlett S. Hexachlorobenzene toxicity in the monkey primordial germ cell without induced porphyria. Reproductive Toxicology 19937 41-47. (https://doi.org/10.1016/0890-6238(93)90008-U)

207 Sims DE, Singh A, Donald A, Jarrell J \& Villeneuve DC. Alteration of primate ovary surface epithelium by exposure to hexachlorobenzene: A quantitative study. Histology and Histopathology 19916 525-529.

208 Babineau KA, Singh A, Jarrell JF \& Villeneuve DC. Surface epithelium of the ovary following oral administration of hexachlorobenzene to the monkey. Journal of Submicroscopic Cytology and Pathology 199123 $457-464$.

209 Arnold DL, Moodie CA, Charbonneau SM, Grice HC, McGuire PF, Bryce FR, Collins BT, Zawidzka ZZ, Krewski DR, Nera EA, et al. Long-term toxicity of hexachlorobenzene in the rat and the effect of dietary vitamin A. Food and Chemical Toxicology 198523 779-793. (https://doi.org/10.1016/0278-6915(85)90278-9)

210 Hadjab S, Maurel D, Cazals Y \& Siaud P. Hexachlorobenzene, a dioxin-like compound, disrupts auditory function in rat. Hearing Research 2004191 125-134. (https://doi.org/10.1016/j. heares.2003.12.017)

211 van Raaij JAGM, Kaptein E, Visser TJ \& van den Berg KJ. Increased glucuronidation of thyroid hormone in hexachlorobenzene-treated rats. Biochemical Pharmacology 199345 627-631. (https://doi. org/10.1016/0006-2952(93)90136-K)

212 Smith AG, Dinsdale D, Cabral JR \& Wright AL. Goitre and wasting induced in hamsters by hexachlorobenzene. Archives of Toxicology 198760 343-349. (https://doi.org/10.1007/BF00295753)

213 Van Raaij JAGM, Frijters CMG \& van den Berg KJ. Hexachlorobenzene-induced hypothyroidism. Involvement of different mechanisms by parent compound and metabolite. Biochemical Pharmacology 199346 1385-1391. (https://doi. org/10.1016/0006-2952(93)90103-4)

214 Alvarez L, Hernández S, Martinez-de-Mena R, Kolliker-Frers R, Obregón MJ \& Kleiman de Pisarev DL. The role of type I and type II 5' deiodinases on hexachlorobenzene-induced alteration of the hormonal thyroid status. Toxicology 2005207 349-362. (https://doi. org/10.1016/j.tox.2004.10.006)

215 Chiappini F, Pontillo C, Randi A, Alvarez L \& Kleiman de Pisarev DL. Hexachlorobenzene induces TGF- $\beta 1$ expression, which is a regulator of p27 and cyclin D1 modifications. Toxicology Letters 2014230 1-9. (https://doi.org/10.1016/j.toxlet.2014.08.002)

216 Chiappini F, Alvarez L, Lux-Lantos V, Randi AS \& Kleiman de Pisarev DL. Hexachlorobenzene triggers apoptosis in rat thyroid follicular cells. Toxicological Sciences 2009108 301-310. (https://doi. org/10.1093/toxsci/kfp016)

217 Muller M, Hess L, Tardivo A, Lajmanovich R, Attademo A, Poletta G, Simoniello MF, Yodice A, Lavarello S, Chialvo D, et al. Neurologic 
dysfunction and genotoxicity induced by low levels of chlorpyrifos. Neurotoxicology 201445 22-30. (https://doi.org/10.1016/j. neuro.2014.08.012)

218 Whyatt RM, Barr DB, Camann DE, Kinney PL, Barr JR, Andrews HF, Hoepner LA, Garfinkel R, Hazi Y, Reyes A, et al. Contemporaryuse pesticide in personal air samples during pregnancy and blood samples at delivery among urban minority mothers and newborns. Environmental Health Perspectives 2003111 749-756. (https://doi. $\operatorname{org} / 10.1289 /$ ehp.5768)

219 Perera FP, Illman SM, Kinney PL, Whyatt RM, Kelvin EA, Shepard P, Evans D, Fullilove M, Ford J, Miller RL, et al. The challenge of preventing environmentally related disease in young children: community-based research in New York City. Environmental Health Perspectives 2002110 197-204. (https://doi.org/10.1289/ ehp.02110197)

220 Whyatt RM, Rauh V, Barr DB, Camann DE, Andrews HF, Garfinkel R, Hoepner LA, Diaz D, Dietrich J, Reyes A, et al. Prenatal insecticide exposures and birth weight and length among an urban minority cohort. Environmental Health Perspectives 2004112 1125-1132. (https://doi.org/10.1289/ehp.6641)

221 Farahat T, Hala Mohammed S, Sanad Z \& NA F. Organophosphate pesticide exposure during pregnancy and adverse perinatal outcome. Journal of Women's Health Care 20165 1-4.

222 Abdel-Rahman A, Blumenthal GM, Abou-Donia SA, Ali FA, Abdel-Monem AE \& Abou-Donia MB. Pharmacokinetic profile and placental transfer of a single intravenous injection of [(14)C] chlorpyrifos in pregnant rats. Archives of Toxicology $200276452-459$. (https://doi.org/10.1007/s00204-002-0366-2)

223 Rauh VA, Garfinkel R, Perera FP, Andrews HF, Hoepner L, Barr DB, Whitehead R, Tang D \& Whyatt RW. Impact of prenatal chlorpyrifos exposure on neurodevelopment in the first 3 years of life among inner-city children. Pediatrics 2006118 e1845-e1859. (https://doi. org/10.1542/peds.2006-0338)

224 De Cock M, Maas YGH \& Van De Bor M. Does perinatal exposure to endocrine disruptors induce autism spectrum and attention deficit hyperactivity disorders? Review. Acta Paediatrica, International Journal of Paediatrics 2012101 811-818. (https://doi.org/10.1111/j.16512227.2012.02693.x)

225 Rauh V, Arunajadai S, Horton M, Perera F, Hoepner L, Barr DB \& Whyatt R. Seven-year neurodevelopmental scores and prenatal exposure to chlorpyrifos, a common agricultural pesticide. Environmental Health Perspectives 2011119 1196-1201. (https://doi. org/10.1289/ehp.1003160)

226 Rauh VA, Garcia WE, Whyatt RM, Horton MK, Barr DB \& Louis ED. Prenatal exposure to the organophosphate pesticide chlorpyrifos and childhood tremor. Neurotoxicology 201551 80-86. (https://doi. org/10.1016/j.neuro.2015.09.004)

227 Eaton DL, Daroff RB, Autrup H, Bridges J, Buffler P, Costa LG, Coyle J, McKhann G, Mobley WC, Nadel L, et al. Review of the toxicology of chlorpyrifos with an emphasis on human exposure and neurodevelopment. Critical Reviews in Toxicology 200838 1-125. (https://doi.org/10.1080/10408440802272158)

228 Reiss R, Chang ET, Richardson RJ \& Goodman M. A review of epidemiologic studies of low-level exposures to organophosphorus insecticides in non-occupational populations. Critical Reviews in Toxicology 201545 531-641. (https://doi.org/10.3109/10408444.2015 .1043976)

229 Timchalk C, Nolan RJ, Mendrala AL, Dittenber DA, Brzak KA \& Mattsson JL. A physiologically based pharmacokinetic and pharmacodynamic (PBPK/PD) model for the organophosphate insecticide chlorpyrifos in rats and humans. Toxicological Sciences 200266 34-53. (https://doi.org/10.1093/toxsci/66.1.34)

230 United States Environmental Protection Agency. EPA administrator Pruitt denies petition to ban widely used pesticide. Washington DC, USA: EPA, 2017. (available at: https://www.epa.gov/newsreleases/epaadministrator-pruitt-denies-petition-ban-widely-used-pesticide-0)
231 Trasande L. When enough data are not enough to enact policy: The failure to ban chlorpyrifos. PLoS Biology 201715 e2003671. (https:// doi.org/10.1371/journal.pbio.2003671)

232 Fortenberry GZ, Hu H, Turyk M, Barr DB \& Meeker JD. Association between urinary 3,5,6-trichloro-2-pyridinol, a metabolite of chlorpyrifos and chlorpyrifos-methyl, and serum T4 and TSH in NHANES 1999-2002. Science of the Total Environment 2012424 351-355. (https://doi.org/10.1016/j.scitotenv.2012.02.039)

233 Meeker JD, Barr DB \& Hauser R. Thyroid hormones in relation to urinary metabolites of non-persistent insecticides in men of reproductive age. Reproductive Toxicology 200622 437-442. (https:// doi.org/10.1016/j.reprotox.2006.02.005)

234 Slotkin TA, Cooper EM, Stapleton HM \& Seidler FJ. Does thyroid disruption contribute to the developmental neurotoxicity of chlorpyrifos? Environmental Toxicology and Pharmacology 201336 284-287. (https://doi.org/10.1016/j.etap.2013.04.003)

235 De Angelis S, Tassinari R, Maranghi F, Eusepi A, Di Virgilio A, Chiarotti F, Ricceri L, Venerosi Pesciolini A, Gilardi E, Moracci G, et al. Developmental exposure to chlorpyrifos induces alterations in thyroid and thyroid hormone levels without other toxicity signs in CD-1 mice. Toxicological Sciences 2009108 311-319. (https://doi. org/10.1093/toxsci/kfp017)

236 Silva JG, Boareto AC, Schreiber AK, Redivo DD, Gambeta E, Vergara F, Morais H, Zanoveli JM \& Dalsenter PR. Chlorpyrifos induces anxiety-like behavior in offspring rats exposed during pregnancy. Neuroscience Letters 2017641 94-100. (https://doi.org/10.1016/j. neulet.2017.01.053)

237 Ghisari M \& Bonefeld-Jorgensen EC. Impact of environmental chemicals on the thyroid hormone function in pituitary rat GH3 cells. Molecular and Cellular Endocrinology 2005244 31-41.

238 Jeong SH, Kim BY, Kang HG, Ku HO \& Cho JH. Effect of chlorpyrifos-methyl on steroid and thyroid hormones in rat F0and F1-generations. Toxicology 2006220 189-202. (https://doi. org/10.1016/j.tox.2006.01.005)

239 Ventura C, Núñez M, Miret N, Martinel Lamas D, Randi A, Venturino A, Rivera E \& Cocca C. Differential mechanisms of action are involved in chlorpyrifos effects in estrogen-dependent or -independent breast cancer cells exposed to low or high concentrations of the pesticide. Toxicology Letters 2012213 184-193. (https://doi.org/10.1016/j.toxlet.2012.06.017)

240 Grünfeld HT \& Bonefeld-Jorgensen EC. Effect of in vitro estrogenic pesticides on human oestrogen receptor $\alpha$ and $\beta$ mRNA levels. Toxicology Letters 2004151 467-480.

241 Yu K, Li G, Feng W, Liu L, Zhang J, Wu W, Xu L \& Yan Y. Chlorpyrifos is estrogenic and alters embryonic hatching, cell proliferation and apoptosis in zebrafish. Chemico-Biological Interactions 2015239 26-33. (https://doi.org/10.1016/j.cbi.2015.06.010)

242 Ventura C Nieto MR, Bourguignon N, Lux-Lantos V, Rodriguez H, Cao G, Randi A, Cocca C \& Núñez M. Pesticide chlorpyrifos acts as an endocrine disruptor in adult rats causing changes in mammary gland and hormonal balance. Journal of Steroid Biochemistry and Molecular Biology 2016156 1-9. (https://doi.org/10.1016/j. jsbmb.2015.10.010)

243 Viswanath G, Chatterjee S, Dabral S, Nanguneri SR, Divya G \& Roy P. Anti-androgenic endocrine disrupting activities of chlorpyrifos and piperophos. Journal of Steroid Biochemistry and Molecular Biology 120 22-29. (https://doi.org/10.1016/j.jsbmb.2010.02.032)

244 Wegner S, Browne P \& Dix D. Identifying reference chemicals for thyroid bioactivity screening. Reproductive Toxicology $2016 \mathbf{6 5}$ 402-413. (https://doi.org/10.1016/j.reprotox.2016.08.016)

245 Marinovich M, Guizzetti M, Ghilardi F, Viviani B, Corsini E \& Galli CL. Thyroid peroxidase as toxicity target for dithiocarbamates. Archives of Toxicology $1997 \mathbf{7 1}$ 508-512. (https://doi.org/10.1007/ s002040050420)

246 Mallem L, Boulakoud MS \& Franck M. Hypothyroidism after medium exposure to the fungicide maneb in the rabbit Cuniculus lepus.

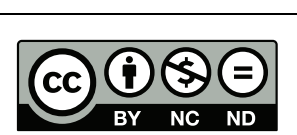

This work is licensed under a Creative Commons Attribution-NonCommercial-NoDerivatives 4.0 International License. 
Communications in Agricultural and Applied Biological Sciences $2006 \mathbf{7 1}$ 91-99.

247 Axelstad M, Boberg J, Nellemann C, Kiersgaard M, Jacobsen PR, Christiansen S, Hougaard KS \& Hass U. Exposure to the widely used fungicide mancozeb causes thyroid hormone disruption in rat dams but no behavioral effects in the offspring. Toxicological Sciences 2011 120 439-446. (https://doi.org/10.1093/toxsci/kfr006)

248 Medda E, Santini F, De Angelis S, Franzellin F, Fiumalbi C, Perico A, Gilardi E, Mechi MT, Marsili A, Citroni A, et al. Iodine nutritional status and thyroid effects of exposure to ethylenebisdithiocarbamates. Environmental Research 2017154 152-159. (https://doi.org/10.1016/j.envres.2016.12.019)

249 Hester SD, Wolf DC, Nesnow S \& Thai SF. Transcriptional profiles in liver from rats treated with tumorigenic and non-tumorigenic triazole conazole fungicides: propiconazole, triadimefon, and myclobutanil. Toxicologic Pathology 200634 879-894. (https://doi. org/10.1080/01926230601047824)

250 Campos É \& Freire C. Exposure to non-persistent pesticides and thyroid function: a systematic review of epidemiological evidence. International Journal of Hygiene and Environmental Health 2016219 481-497. (https://doi.org/10.1016/j.ijheh.2016.05.006)

251 Yadav AK \& Singh TP. Pesticide-induced impairment of thyroid physiology in the freshwater catfish, Heteropneustes fossilis. Environmental Pollution 198743 29-38. (https://doi. org/10.1016/0269-7491(87)90165-5)

252 Van den Berg KJ, van Raaij JAGM, Bragt PC \& Notten WRF. Interactions of halogenated industrial chemicals with transthyretin and effects on thyroid hormone levels in vivo. Archives of Toxicology 199165 15-19. (https://doi.org/10.1007/BF01973497)

253 Ishihara A, Sawatsubashi S \& Yamauchi K. Endocrine disrupting chemicals: interference of thyroid hormone binding to transthyretins and to thyroid hormone receptors. Molecular and Cellular Endocrinology 2003199 105-117.

254 Sinha N, Lal B \& Singh TP. Carbaryl-induced thyroid dysfunction in the freshwater catfish Clarias batrachus. Ecotoxicology and Environmental Safety 199121 240-247. (https://doi. org/10.1016/0147-6513(91)90062-T)

255 Akhtar N, Kayani SA, Ahmad MM \& Shahab M. Insecticideinduced changes in secretory activity of the thyroid gland in rats. Journal of Applied Toxicology 199616 397-400. (https:// doi.org/10.1002/(SICI)1099-1263(199609)16:5<397::AIDJAT362>3.0.CO;2-Y)

256 Lerro CC, Koutros S, Andreotti G, Friesen MC, Alavanja MC, Blair A, Hoppin JA, Sandler DP, Lubin JH, Ma X, et al. Organophosphate insecticide use and cancer incidence among spouses of pesticide applicators in the Agricultural Health Study. Occupational and Environmental Medicine 201572 736-744. (https://doi.org/10.1136/ oemed-2014-102798)

257 Jin Y, Liu J, Wang L, Chen R, Zhou C, Yang Y, Liu W \& Fu Z. Permethrin exposure during puberty has the potential to enantioselectively induce reproductive toxicity in mice. Environment International 201242 144-151. (https://doi.org/10.1016/j. envint.2011.05.020)

258 Jin Y, Chen R, Sun L, Wang W, Zhou L, Liu W \& Fu Z. Enantioselective induction of estrogen-responsive gene expression by permethrin enantiomers in embryo-larval zebrafish. Chemosphere 200974 1238-1244. (https://doi.org/10.1016/j. chemosphere.2008.11.015)

259 Du G, Shen O, Sun H, Fei J, Lu C, Song L, Xia Y, Wang S \& Wang X. Assessing hormone receptor activities of pyrethroid insecticides and their metabolites in reporter gene assays. Toxicological Sciences 2010 116 58-66. (https://doi.org/10.1093/toxsci/kfq120)

260 Tu W, Xu C, Jin Y, Lu B, Lin C, Wu Y \& Liu W. Permethrin is a potential thyroid-disrupting chemical: in vivo and in silico envidence. Aquatic Toxicology 2016175 39-46. (https://doi. org/10.1016/j.aquatox.2016.03.006)
261 Maiti PK, Kar A, Gupta P \& Chaurasia SS. Loss of membrane integrity and inhibition of type-I iodothyronine 5'-monodeiodinase activity by fenvalerate in female mouse. Biochemical and Biophysical Research Communications 1995214 905-909.

262 Maiti PK \& Kar A. Dimethoate inhibits extrathyroidal $5^{\prime}$-monodeiodination of thyroxine to $3,3^{\prime}, 5$-triiodothyronine in mice: the possible involvement of the lipid peroxidative process. Toxicology Letters 199791 1-6. (https://doi.org/10.1016/S03784274(96)03865-9)

$263 \mathrm{Tu}$ W, Xu C, Lu B, Lin C, Wu Y \& Liu W. Acute exposure to synthetic pyrethroids causes bioconcentration and disruption of the hypothalamus-pituitary-thyroid axis in zebrafish embryos. Science of the Total Environment 2016542 876-885. (https://doi.org/10.1016/j. scitotenv.2015.10.131)

264 Kaul PP, Rastogi A, Hans RK, Seth TD, Seth PK \& Srimal RC. Fenvalerate-induced alterations in circulatory thyroid hormones and calcium stores in rat brain. Toxicology Letters 199689 29-33. (https:// doi.org/10.1016/S0378-4274(96)03778-2)

265 Giray B, Cağlayan A, Erkekoğlu P \& HIncal F. Fenvalerate exposure alters thyroid hormone status in selenium- and/or iodine-deficient rats. Biological Trace Element Research 2010135 233-241. (https://doi. org/10.1007/s12011-009-8506-7)

266 Cotgreave I, Alavian Ghavanini A, Alfaro-Moreno E, Bergman Å, Cederbrant K, Forsby A, Förare J, Gustafsson $\AA$, Hellmold H, Lindberg J, et al.. Pyriproxifen and microcephaly : an investigation of potential ties to the ongoing 'Zika epidemic'. Södertälje, Sweden: The Swedish Center for Toxicology Sciences, 2016. (available at: http:// swetox.se/wp-content/uploads/2016/03/ppf-zika.pdf)

267 van den Berg M, Kypke K, Kotz A, Tritscher A, Lee SY, Magulova K, Fiedler H \& Malisch R. WHO/UNEP global surveys of PCDDs, PCDFs, PCBs and DDTs in human milk and benefit-risk evaluation of breastfeeding. Archives of Toxicology 201791 83-96. (https://doi. org/10.1007/s00204-016-1802-z)

268 Meironyté Guvenius D, Aronsson A, Ekman-Ordeberg G, Bergman Å \& Norén K. Human prenatal and postnatal exposure to polybrominated diphenyl ethers, polychlorinated biphenyls, polychlorobiphenylols, and pentachlorophenol. Environmental Health Perspectives 2003111 1235-1241.

269 Soechitram SD, Athanasiadou M, Hovander L, Bergman Å \& Sauer PJJ. Fetal exposure to PCBs and their hydroxylated metabolites in a Dutch cohort. Environmental Health Perspectives 2004112 1208-1212. (https://doi.org/10.1289/ehp.6424)

270 Fängström B, Strid A, Grandjean P, Weihe P \& Bergman Å. A retrospective study of PBDEs and PCBs in human milk from the Faroe Islands. Environmental Health 2005412.

271 Guvenius DM, Hassanzadeh P, Bergman A \& Norén K. Metabolites of polychlorinated biphenyls in human liver and adipose tissue. Environmental Toxicology and Chemistry 200221 2264-2269. (https:// doi.org/10.1002/etc.5620211102)

272 Valvi D, Mendez MA, Martinez D, Grimalt JO, Torrent M, Sunyer J \& Vrijheid M. Prenatal concentrations of polychlorinated biphenyls, DDE, and DDT and overweight in children: a prospective birth cohort study. Environmental Health Perspectives 2012120 451-457. (https://doi.org/10.1289/ehp.1103862)

273 Caspersen IH, Aase H, Biele G, Brantsæter AL, Haugen M, Kvalem HE, Skogan AH, Zeiner P, Alexander J, Meltzer HM \& Knutsen HK. The influence of maternal dietary exposure to dioxins and PCBs during pregnancy on ADHD symptoms and cognitive functions in Norwegian preschool children. Environment International 201694 649-660. (https://doi.org/10.1016/j.envint.2016.06.033)

274 Stewart PW, Lonky E, Reihman J, Pagano J, Gump BB \& Darvill T. The relationship between prenatal PCB exposure and intelligence (IQ) in 9-year-old children. Environmental Health Perspectives 2008116 1416-1422. (https://doi.org/10.1289/ehp.11058)

275 Walkowiak J, Wiener JA, Fastabend A, Heinzow B, Krämer U, Schmidt E, Steingrüber HJ, Wundram S \& Winneke G. Environmental

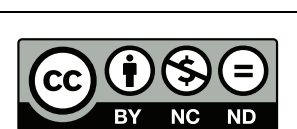

This work is licensed under a Creative Commons Attribution-NonCommercial-NoDerivatives 4.0 International License. 
exposure to polychlorinated biphenyls and quality of the home environment: effects on psychodevelopment in early childhood. Lancet 2001358 1602-1607. (https://doi.org/10.1016/S01406736(01)06654-5)

276 Verner MA, Plusquellec P, Desjardins JL, Cartier C, Haddad S, Ayotte P, Dewailly É \& Muckle G. Prenatal and early-life polychlorinated biphenyl (PCB) levels and behavior in Inuit preschoolers. Environment International 201578 90-94. (https://doi. org/10.1016/j.envint.2015.02.004)

277 Ethier AA, Muckle G, Jacobson SW, Ayotte P, Jacobson JL \& SaintAmour D. Assessing new dimensions of attentional functions in children prenatally exposed to environmental contaminants using an adapted Posner paradigm. Neurotoxicology and Teratology 201551 27-34. (https://doi.org/10.1016/j.ntt.2015.07.005)

278 Schantz SL, Widholm JJ \& Rice DC. Effects of PCB exposure on neuropsychological function in children. Environmental Health Perspectives 2003111 357-576. (https://doi.org/10.1289/ehp.5461)

279 Behforooz B, Newman J, Gallo MV \& Schell LM. PCBs and measures of attention and impulsivity on a continuous performance task of young adults. Neurotoxicology and Teratology 201764 29-36.

280 Šovčíková E, Wimmerová S, Strémy M, Kotianová J, Loffredo CA, Murínová LP, Chovancová J, Čonka K, Lancz K \& Trnovec T. Simple reaction time in 8-9-year old children environmentally exposed to PCBs. Neurotoxicology 201551 138-144. (https://doi.org/10.1016/j. neuro.2015.10.005)

281 Berghuis SA, Soechitram SD, Hitzert MM, Sauer PJJ \& Bos AF. Prenatal exposure to polychlorinated biphenyls and their hydroxylated metabolites is associated with motor development of threemonth-old infants. Neurotoxicology 201338 124-130. (https://doi. org/10.1016/j.neuro.2013.07.003)

282 Lyall K, Croen LA, Sjödin A, Yoshida CK, Zerbo O, Kharrazi M \& Windham GC. Polychlorinated biphenyl and organochlorine pesticide concentrations in maternal mid-pregnancy serum samples: association with Autism spectrum disorder and intellectual disability. Environmental Health Perspectives 2017125 474-480. (https://doi. org/10.1289/EHP277)

283 Cheslack-Postava K, Rantakokko PV, Hinkka-Yli-Salomäki S, Surcel HM, McKeague IW, Kiviranta HA, Sourander A \& Brown AS. Maternal serum persistent organic pollutants in the Finnish Prenatal Study of Autism: a pilot study. Neurotoxicology and Teratology 201338 1-5. (https://doi.org/10.1016/j.ntt.2013.04.001)

284 Neugebauer J, Wittsiepe J, Kasper-Sonnenberg M, Schöneck N, Schölmerich A \& Wilhelm M. The influence of low level pre- and perinatal exposure to PCDD/Fs, PCBs, and lead on attention performance and attention-related behavior among German school-aged children: results from the Duisburg Birth Cohort Study. International Journal of Hygiene and Environmental Health 2015218 153-162. (https://doi.org/10.1016/j.ijheh.2014.09.005)

285 Verner MA, Hart JE, Sagiv SK, Bellinger DC, Altshul LM \& Korrick SA. Measured prenatal and estimated postnatal levels of polychlorinated biphenyls (PCBs) and ADHD-related behaviors in 8-year-old children. Environmental Health Perspectives 2015123 888-894. (https://doi. org/10.1289/ehp.1408084)

286 Bergkvist C, Berglund M, Glynn A, Wolk A \& Åkesson A. Dietary exposure to polychlorinated biphenyls and risk of myocardial infarction - a population-based prospective cohort study. International Journal of Cardiology 2015183 242-248. (https://doi. org/10.1016/j.ijcard.2015.01.055)

287 Langer P, Tajtáková M, Kocan A, Petrík J, Koska J, Ksinantová L, Rádiková Z, Ukropec J, Imrich R, Hucková M, et al. Thyroid ultrasound volume, structure and function after long-term high exposure of large population to polychlorinated biphenyls, pesticides and dioxin. Chemosphere 200769 118-127. (https://doi org/10.1016/j.chemosphere.2007.04.039)

288 Langer P, Tajtakova M, Kocan A, Drobna B, Kostalova L, Fodor G $\&$ Klimes I. Tyroid volume, iodine intake, autoimmune thyroid disorders, inborn factors, and endocrine disruptors: twenty-year studies of multiple effects puzzle in slovakia. Endocrine Regulations 201246 191-203. (https://doi.org/10.4149/endo_2012_04_191)

289 McKinney JD \& Waller CL. Polychlorinated biphenyls as hormonally active structural analogues. Environmental Health Perspectives 1994 102 290-297. (https://doi.org/10.1289/ehp.94102290)

290 Otake T, Yoshinaga J, Enomoto T, Matsuda M, Wakimoto T, Ikegami M, Suzuki E, Naruse H, Yamanaka T, Shibuya N, et al. Thyroid hormone status of newborns in relation to in utero exposure to PCBs and hydroxylated PCB metabolites. Environmental Research 2007105 240-246. (https://doi.org/10.1016/j.envres.2007.03.010)

291 Herbstman JB, Sjödin A, Apelberg BJ, Witter FR, Halden RU, Patterson DG, Panny SR, Needham LL \& Goldman LR. Birth delivery mode modifies the associations between prenatal polychlorinated biphenyl (PCB) and polybrominated diphenyl ether (PBDE) and neonatal thyroid hormone levels. Environmental Health Perspectives 2008116 1376-1382. (https://doi.org/10.1289/ehp.11379)

292 Brucker-Davis F, Ferrari P, Boda-Buccino M, Wagner-Mahler K, Pacini P, Gal J, Azuar P \& Fenichel P. Cord blood thyroid tests in boys born with and without cryptorchidism: correlations with birth parameters and in utero xenobiotics exposure. Thyroid 201121 1133-1141. (https://doi.org/10.1089/thy.2010.0459)

293 Dallaire R, Muckle G, Dewailly E, Jacobson SW, Jacobson JL, Sandanger TM, Sandau CD \& Ayotte P. Thyroid hormone levels of pregnant inuit women and their infants exposed to environmental contaminants. Environmental Health Perspectives 2009117 1014-1020. (https://doi.org/10.1289/ehp.0800219)

294 Darnerud PO, Lignell S, Glynn A, Aune M, Törnkvist A \& Stridsberg M. POP levels in breast milk and maternal serum and thyroid hormone levels in mother-child pairs from Uppsala, Sweden. Environment International 201036 180-187. (https://doi. org/10.1016/j.envint.2009.11.001)

295 Leijs MM, ten Tusscher GW, Olie K, van Teunenbroek T, van Aalderen WM, de Voogt P, Vulsma T, Bartonova A, Krayer von Krauss M, Mosoiu C, et al. Thyroid hormone metabolism and environmental chemical exposure. Environmental Health 201211 S10. (https://doi.org/10.1186/1476-069X-11-S1-S10)

296 Grimm FA, Lehmler HJ, He X, Robertson LW \& Duffel MW. Sulfated metabolites of polychlorinated biphenyls are high-affinity ligands for the thyroid hormone transport protein transthyretin. Environmental Health Perspectives 2013121 657-662. (https://doi.org/10.1289/ ehp.1206198)

297 Álvarez-Pedrerol M, Ribas-Fitó N, Torrent M, Carrizo D, GarciaEsteban R, Grimalt JO \& Sunyer J. Thyroid disruption at birth due to prenatal exposure to $\beta$-hexachlorocyclohexane. Environment International 200834 737-740. (https://doi.org/10.1016/j. envint.2007.12.001)

298 Hisada A, Shimodaira K, Okai T, Watanabe K, Takemori H, Takasuga T, Koyama M, Watanabe N, Suzuki E, Shirakawa M, et al. Associations between levels of hydroxylated PCBs and PCBs in serum of pregnant women and blood thyroid hormone levels and body size of neonates. International Journal of Hygiene and Environmental Health 2014217 546-553. (https://doi.org/10.1016/j.ijheh.2013.10.004)

299 De Cock M, de Boer MR, Govarts E, Iszatt N, Palkovicova L, Lamoree MH, Schoeters G, Eggesbø M, Trnovec T, Legler J, et al. Thyroid-stimulating hormone levels in newborns and early life exposure to endocrine-disrupting chemicals: analysis of three European mother-child cohorts. Pediatric Research 201782 429-437. (https://doi.org/10.1038/pr.2017.50)

300 Crofton KM, Craft ES, Hedge JM, Gennings C, Simmons JE, Carchman RA, Carter WH Jr \& DeVito MJ. Thyroid-hormonedisrupting chemicals: evidence for dose-dependent additivity or synergism. Environmental Health Perspectives 2005113 1549-1554 (https://doi.org/10.1289/ehp.8195)

301 Katarzyńska D, Hrabia A, Kowalik K \& Sechman A. Comparison of the in vitro effects of TCDD, PCB 126 and PCB 153 on thyroid-restricted

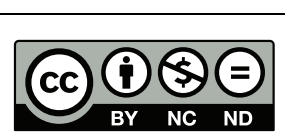

This work is licensed under a Creative Commons Attribution-NonCommercial-NoDerivatives 4.0 International License. 
gene expression and thyroid hormone secretion by the chicken thyroid gland. Environmental Toxicology and Pharmacology 201539 496-503. (https://doi.org/10.1016/j.etap.2015.01.016)

302 Ahmed RG. Early weaning PCB95 exposure alters the neonatal endocrine system: thyroid adipokine dysfunction. Journal of Endocrinology 2013219 205-215. (https://doi.org/10.1530/JOE-130302)

303 Meerts IATM. Developmental exposure to 4-hydroxy-2,3,3', $4^{\prime}, 5$ pentachlorobiphenyl (4-OH-CB107): long-term effects on brain development, behavior, and brain stem auditory evoked potentials in rats. Toxicological Sciences 200482 207-218. (https://doi.org/10.1093/ toxsci/kfh252)

304 Reilly MP, Weeks CD, Topper VY, Thompson LM, Crews D \& Gore AC. The effects of prenatal PCBs on adult social behavior in rats. Hormones and Behavior 201573 47-55. (https://doi. org/10.1016/j.yhbeh.2015.06.002)

305 Gutleb AC, Cenijn P, Velzen Mv, Lie E, Ropstad E, Skaare JU, Malmberg T, Bergman A, Gabrielsen GW \& Legler J. In vitro assay shows that PCB metabolites completely saturate thyroid hormone transport capacity in blood of wild polar bears (Ursus maritimus). Environmental Science and Technology 201044 3149-3154. (https:// doi.org/10.1021/es903029j)

306 Yang H, Chen H, Guo H, Li W, Tang J, Xu B, Sun M, Ding G, Jiang L, Cui D, Zheng X, et al. Molecular mechanisms of $2,3^{\prime}, 4,4^{\prime}, 5$-pentachlorobiphenyl-induced thyroid dysfunction in FRTL-5 cells. PLOS ONE 201510 e0120133. (https://doi.org/10.1371/ journal.pone.0120133)

307 Guo H, Yang H, Chen H, Li W, Tang J, Cheng P, Xie Y, Liu Y, Ding G, Cui D, et al. Molecular mechanisms of human thyrocyte dysfunction induced by low concentrations of polychlorinated biphenyl 118 through the Akt/FoxO3a/NIS pathway. Journal of Applied Toxicology 201535 992-998. (https://doi.org/10.1002/jat.3032)

308 Xu B, Yang H, Sun M, Chen H, Jiang L, Zheng X, Ding G, Liu Y, Sheng Y, Cui D, et al. 2,3',4,4',5-pentachlorobiphenyl induces inflammatory responses in the thyroid through JNK and Aryl hydrocarbon receptor-mediated pathway. Toxicological Sciences 2016 149 300-311. (https://doi.org/10.1093/toxsci/kfv235)

309 Ekuase EJ, Liu Y, Lehmler HJ, Robertson LW \& Duffel MW. Structureactivity relationships for hydroxylated polychlorinated biphenyls as inhibitors of the sulfation of dehydroepiandrosterone catalyzed by human hydroxysteroid sulfotransferase SULT2A1. Chemical Research in Toxicology 201124 1720-1728. (https://doi.org/10.1021/ tx200260h)

310 Soechitram SD, Berghuis SA, Visser TJ \& Sauer PJJ. Polychlorinated biphenyl exposure and deiodinase activity in young infants. Science of the Total Environment 2017574 1117-1124. (https://doi. org/10.1016/j.scitotenv.2016.09.098)

311 Dickerson SM, Cunningham SL, Patisaul HB, Woller MJ \& Gore AC. Endocrine disruption of brain sexual differentiation by developmental PCB exposure. Endocrinology 2011152 581-594. (https://doi.org/10.1210/en.2010-1103)

312 Walker DM, Goetz BM \& Gore AC. Dynamic postnatal developmental and sex-specific neuroendocrine effects of prenatal polychlorinated biphenyls in rats. Molecular Endocrinology 201428 99-115. (https://doi.org/10.1210/me.2013-1270)

313 deCastro BR, Korrick SA, Spengler JD \& Soto AM. Estrogenic activity of polychlorinated biphenyls present in human tissue and the environment. Environmental Science and Technology $2006 \mathbf{4 0}$ 2819-2825. (https://doi.org/10.1021/es051667u)

314 Zhang Q, Lu M, Wang C, Du J, Zhou P \& Zhao M. Characterization of estrogen receptor $\alpha$ activities in polychlorinated biphenyls by in vitro dual-luciferase reporter gene assay. Environmental Pollution 2014 189 169-175. (https://doi.org/10.1016/j.envpol.2014.03.001)

315 Hamers T, Kamstra JH, Cenijn PH, Pencikova K, Palkova L, Simeckova P, Vondracek J, Andersson PL, Stenberg M \& Machala M. In vitro toxicity profiling of ultrapure non-dioxin- like polychlorinated biphenyl congeners and their relative toxic contribution to PCB mixtures in humans. Toxicological Sciences 2011 121 88-100. (https://doi.org/10.1093/toxsci/kfr043)

316 Flor S, He X, Lehmler HJ \& Ludewig G. Estrogenicity and androgenicity screening of PCB sulfate monoesters in human breast cancer MCF-7 cells. Environmental Science and Pollution Research 2016 23 2186-2200. (https://doi.org/10.1007/s11356-015-5142-y)

317 Lyche JL, Rosseland C, Berge G \& Polder A. Human health risk associated with brominated flame-retardants (BFRs). Environment International 201574 170-180. (https://doi.org/10.1016/j. envint.2014.09.006)

318 Law RJ, Covaci A, Harrad S, Herzke D, Abdallah MA, Fernie K, Toms LM \& Takigami H. Levels and trends of PBDEs and HBCDs in the global environment: status at the end of 2012. Environment International 201465 147-158. (https://doi.org/10.1016/j. envint.2014.01.006)

319 Fliedner A, Lohmann N, Rüdel H, Teubner D, Wellmitz J \& Koschorreck J. Current levels and trends of selected EU Water Framework Directive priority substances in freshwater fish from the German environmental specimen bank. Environmental Pollution 2016 216 866-876. (https://doi.org/10.1016/j.envpol.2016.06.060)

320 Sjödin A, Jones RS, Caudill SP, Wong LY, Turner WE \& Calafat AM. Polybrominated diphenyl ethers, polychlorinated biphenyls, and persistent pesticides in serum from the national health and nutrition examination survey: 2003-2008. Environmental Science and Technology 201448 753-760.

321 Vizcaino E, Grimalt JO, Fernández-Somoano A \& Tardon A. Transport of persistent organic pollutants across the human placenta. Environment International 201465 107-115. (https://doi. org/10.1016/j.envint.2014.01.004)

322 Choi G, Kim S, Kim S, Kim S, Choi Y, Kim HJ, Lee JJ, Kim SY, Lee S, Moon HB, et al. Occurrences of major polybrominated diphenyl ethers (PBDEs) in maternal and fetal cord blood sera in Korea. Science of the Total Environment 2014 491-492 219-226. (https://doi. org/10.1016/j.scitotenv.2014.02.071)

323 Gómara B, Herrero L, Ramos JJ, Mateo JR, Fernández MA, García JF \& González MJ. Distribution of polybrominated diphenyl ethers in human umbilical cord serum, paternal serum, maternal serum, placentas, and breast milk from madrid population, Spain. Environmental Science and Technology 200741 6961-6968.

324 Zhang H, Yolton K, Webster GM, Sjödin A, Calafat AM, Dietrich KN, Xu Y, Xie C, Braun JM, Lanphear BP, et al. Prenatal PBDE and PCB exposures and reading, cognition, and externalizing behavior in children. Environmental Health Perspectives 2017125 746-752. (https://doi.org/10.1289/EHP478)

325 Braun JM, Yolton K, Stacy SL, Erar B, Papandonatos GD, Bellinger DC, Lanphear BP \& Chen A. Prenatal environmental chemical exposures and longitudinal patterns of child neurobehavior. Neurotoxicology 201762 192-199. (https://doi. org/10.1016/j.neuro.2017.07.027)

326 Vuong AM, Braun JM, Yolton K, Xie C, Webster GM, Sjödin A, Dietrich KN, Lanphear BP \& Chen A. Prenatal and postnatal polybrominated diphenyl ether exposure and visual spatial abilities in children. Environmental Research 2017153 83-92. (https://doi. org/10.1016/j.envres.2016.11.020)

327 Sagiv SK, Kogut K, Gaspar FW, Gunier RB, Harley KG, Parra K, Villaseñor D, Bradman A, Holland N \& Eskenazi B. Prenatal and childhood polybrominated diphenyl ether (PBDE) exposure and attention and executive function at 9-12 years of age. Neurotoxicology and Teratology 522015 151-161. (https://doi.org/10.1016/j. ntt.2015.08.001)

328 Chen A, Yolton K, Rauch SA, Webster GM, Hornung R, Sjödin A, Dietrich KN \& Lanphear BP. Prenatal polybrominated diphenyl ether exposures and neurodevelopment in U.S. children through 5 years of age: the home study. Environmental Health Perspectives 2014122 856-862. (https://doi.org/10.1289/ehp.1307562) http://www.endocrineconnections.org

https://doi.org/10.1530/EC-18-0029
() 2018 The authors

Published by Bioscientifica Ltd
This work is licensed under a Creative Commons Attribution-NonCommercial-NoDerivatives 4.0 International License. 
329 Eskenazi B, Chevrier J, Rauch SA, Kogut K, Harley KG, Johnson C, Trujillo C, Sjödin A \& Bradman A. In utero and childhood polybrominated diphenyl ether (PBDE) exposures and neurodevelopment in the CHAMACOS study. Environmental Health Perspectives 2013121 257-262. (https://doi.org/10.1289/ ehp.121-A257)

330 Cowell WJ, Lederman SA, Sjödin A, Jones R, Wang S, Perera FP, Wang R, Rauh VA \& Herbstman JB. Prenatal exposure to polybrominated diphenyl ethers and child attention problems at 3-7 years. Neurotoxicology and Teratology 201552 143-150. (https://doi. org/10.1016/j.ntt.2015.08.009)

331 Ding G, Yu J, Cui C, Chen L, Gao Y, Wang C, Zhou Y \& Tian Y. Association between prenatal exposure to polybrominated diphenyl ethers and young children's neurodevelopment in China. Environmental Research 2015142 104-111. (https://doi.org/10.1016/j. envres.2015.06.008)

332 Herbstman JB \& Mall JK. Developmental exposure to polybrominated diphenyl ethers and neurodevelopment. Current Environmental Health Reports 20141 101-112. (https://doi.org/10.1007/s40572-014-0010-3)

333 Vuong AM, Yolton K, Poston KL, Xie C, Webster GM, Sjödin A, Braun JM, Dietrich KN, Lanphear BP \& Chen A. Childhood polybrominated diphenyl ether (PBDE) exposure and executive function in children in the HOME Study. International Journal of Hygiene and Environmental Health 2017221 87-94. (https://doi. org/10.1016/j.ijheh.2017.10.006)

334 Naert C, Van Peteghem C, Kupper J, Jenni L \& Naegeli H. Distribution of polychlorinated biphenyls and polybrominated diphenyl ethers in birds of prey from Switzerland. Chemosphere 2007 68 977-987. (https://doi.org/10.1016/j.chemosphere.2007.01.009)

335 Zhang H, Li X, Nie J \& Niu Q. Lactation exposure to BDE-153 damages learning and memory, disrupts spontaneous behavior and induces hippocampus neuron death in adult rats. Brain Research 2013 1517 44-56. (https://doi.org/10.1016/j.brainres.2013.04.014)

336 Gee JR \& Moser VC. Acute postnatal exposure to brominated diphenylether 47 delays neuromotor ontogeny and alters motor activity in mice. Neurotoxicology and Teratology 200830 79-87.

337 Eriksson P, Jakobsson E \& Fredriksson A. Brominated flame retardants: a novel class of developmental neurotoxicants in our environment? Environmental Health Perspectives 2001109 903-908. (https://doi.org/10.1289/ehp.01109903)

338 Branchi I, Capone F, Alleva E \& Costa LG. Polybrominated diphenyl ethers: neurobehavioral effects following developmental exposure. Neurotoxicology 200324 449-462. (https://doi.org/10.1016/S0161813X(03)00020-2)

339 Gassmann K, Schreiber T, Dingemans MM, Krause G, Roderigo C, Giersiefer S, Schuwald J, Moors M, Unfried K, Bergman A, et al. BDE47 and 6-OH-BDE-47 modulate calcium homeostasis in primary fetal human neural progenitor cells via ryanodine receptor-independent mechanisms. Archives of Toxicology 201488 1537-1548. (https://doi. org/10.1007/s00204-014-1217-7)

340 Costa LG, de Laat R, Tagliaferri S \& Pellacani C. A mechanistic view of polybrominated diphenyl ether (PBDE) developmental neurotoxicity. Toxicology Letters 2014230 282-294. (https://doi. org/10.1016/j.toxlet.2013.11.011)

341 Dingemans MML, Ramakers GM, Gardoni F, van Kleef RG, Bergman A, Di Luca M, van den Berg M, Westerink RH \& Vijverberg HP. Neonatal exposure to brominated flame retardant BDE-47 reduces long-term potentiation and postsynaptic protein levels in mouse hippocampus. Environmental Health Perspectives 2007 115 865-870. (https://doi.org/10.1289/ehp.9860)

342 Bradner JM, Suragh TA \& Caudle WM. Alterations to the circuitry of the frontal cortex following exposure to the polybrominated diphenyl ether mixture, DE-71. Toxicology 2013312 48-55. (https:// doi.org/10.1016/j.tox.2013.07.015)

343 Bradner JM, Suragh TA, Wilson WW, Lazo CR, Stout KA, Kim HM, Wang MZ, Walker DI, Pennell KD, Richardson JR, et al. Exposure

http://www.endocrineconnections.org https://doi.org/10.1530/EC-18-0029
(C) 2018 The authors Published by Bioscientifica Ltd to the polybrominated diphenyl ether mixture DE-71 damages the nigrostriatal dopamine system: role of dopamine handling in neurotoxicity. Experimental Neurology 2013241 138-147. (https://doi. org/10.1016/j.expneurol.2012.12.013)

344 Jacobson MH, Barr DB, Marcus M, Muir AB, Lyles RH, Howards PP, Pardo L \& Darrow LA. Serum polybrominated diphenyl ether concentrations and thyroid function in young children. Environmental Research 2016149 222-230. (https://doi.org/10.1016/j. envres.2016.05.022)

345 Xu X, Liu J, Zeng X, Lu F, Chen A \& Huo X. Elevated serum polybrominated diphenyl ethers and alteration of thyroid hormones in children from Guiyu, China. PLoS ONE 20149 e113699. (https:// doi.org/10.1371/journal.pone.0113699)

346 Makey CM, McClean MD, Braverman LE, Pearce EN, He XM, Sjödin A, Weinberg JM \& Webster TF. Polybrominated diphenyl ether exposure and thyroid function tests in North American adults. Environmental Health Perspectives 2016124 420-425. (https://doi. org/10.1289/ehp.1509755)

347 Kiciński M, Viaene MK, Den Hond E, Schoeters G, Covaci A, Dirtu AC, Nelen V, Bruckers L, Croes K, Sioen I, et al. Neurobehavioral function and low-level exposure to brominated flame retardants in adolescents: a cross-sectional study. Environmental Health 201211 86. (https://doi.org/10.1186/1476-069X-11-86)

348 GuanGen H, Ding G, Lou X, Wang X, Han J, Shen H, Zhou Y $\&$ Du L. Correlations of PCBs, DIOXIN, and PBDE with TSH in children's blood in areas of computer E-waste recycling*. Biomedical and Environmental Sciences 201124 112-116. (https://doi. org/10.3967/0895-3988.2011.02.004)

349 Abdelouahab N, Langlois MF, Lavoie L, Corbin F, Pasquier JC \& Takser L. Maternal and cord-blood thyroid hormone levels and exposure to polybrominated diphenyl ethers and polychlorinated biphenyls during early pregnancy. American Journal of Epidemiology 2013178 701-713. (https://doi.org/10.1093/aje/kwt141)

350 Zhao X, Wang H, Li J, Shan Z, Teng W \& Teng X. The correlation between polybrominated diphenyl ethers (PBDES) and thyroid hormones in the general population: a meta-analysis. PLOS ONE 201510 e0126989. (https://doi.org/10.1371/journal. pone.0126989)

351 Lee E, Kim TH, Choi JS, Nabanata P, Kim NY, Ahn MY, Jung KK, Kang IH, Kim TS, Kwack SJ, et al. Evaluation of liver and thyroid toxicity in Sprague-Dawley rats after exposure to polybrominated diphenyl ether BDE-209. Journal of Toxicological Sciences 201035 535-545. (https://doi.org/10.2131/jts.35.535)

352 Miller VM, Sanchez-Morrissey S, Brosch KO \& Seegal RF. Developmental coexposure to polychlorinated biphenyls and polybrominated diphenyl ethers has additive effects on circulating thyroxine levels in rats. Toxicological Sciences 2012127 76-83. (https://doi.org/10.1093/toxsci/kfs089)

353 Kodavanti PRS, Coburn CG, Moser VC, MacPhail RC, Fenton SE, Stoker TE, Rayner JL, Kannan K \& Birnbaum LS. Developmental exposure to a commercial PBDE Mixture, DE-71: neurobehavioral, hormonal, and reproductive effects. Toxicological Sciences 2010116 297-312. (https://doi.org/10.1093/toxsci/kfq105)

354 Richardson VM, Staskal DF, Ross DG, Diliberto JJ, DeVito MJ \& Birnbaum LS. Possible mechanisms of thyroid hormone disruption in mice by BDE 47, a major polybrominated diphenyl ether congener. Toxicology and Applied Pharmacology 2008226 244-250. (https://doi. org/10.1016/j.taap.2007.09.015)

355 Ren XM, Guo LH, Gao Y, Zhang BT \& Wan B. Hydroxylated polybrominated diphenyl ethers exhibit different activities on thyroid hormone receptors depending on their degree of bromination. Toxicology and Applied Pharmacology 2013268 256-263. (https://doi.org/10.1016/j.taap.2013.01.026)

356 Li F, Xie Q, Li X, Li N, Chi P, Chen J, Wang Z \& Hao C. Hormone activity of hydroxylated polybrominated diphenyl ethers on human thyroid receptor- $\beta$ : in vitro and in silico investigations. Environmental

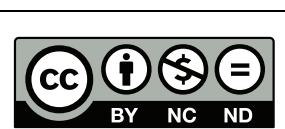

This work is licensed under a Creative Commons Attribution-NonCommercial-NoDerivatives 4.0 International License. 
Health Perspectives 2010118 602-606. (https://doi.org/10.1289/ ehp.0901457)

357 Kitamura S, Jinno N, Suzuki T, Sugihara K, Ohta S, Kuroki H \& Fujimoto N. Thyroid hormone-like and estrogenic activity of hydroxylated PCBs in cell culture. Toxicology 2005208 377-387. (https://doi.org/10.1016/j.tox.2004.11.037)

358 Schriks M, Roessig JM, Murk AJ \& Furlow JD. Thyroid hormone receptor isoform selectivity of thyroid hormone disrupting compounds quantified with an in vitro reporter gene assay. Environmental Toxicology and Pharmacology 200723 302-307. (https:// doi.org/10.1016/j.etap.2006.11.007)

359 Kojima H, Takeuchi S, Uramaru N, Sugihara K, Yoshida T \& Kitamura S. Nuclear hormone receptor activity of polybrominated diphenyl ethers and their hydroxylated and methoxylated metabolites in transactivation assays using Chinese hamster ovary cells. Environmental Health Perspectives 2009117 1210-1218. (https:// doi.org/10.1289/ehp.0900753)

360 Ibhazehiebo K, Iwasaki T, Kimura-Kuroda J, Miyazaki W, Shimokawa N \& Koibuchi N. Disruption of thyroid hormone receptor-mediated transcription and thyroid hormone-induced purkinje cell dendrite arborization by Polybrominated diphenyl ethers. Environmental Health Perspectives 2011119 168-175. (https:// doi.org/10.1289/ehp.1002065)

361 Dach K, Bendt F, Huebenthal U, Giersiefer S, Lein PJ, Heuer H \& Fritsche E. BDE-99 impairs differentiation of human and mouse NPCs into the oligodendroglial lineage by species-specific modes of action. Scientific Reports 20177 44861. (https://doi.org/10.1038/ srep44861)

362 Macaulay LJ, Chen A, Rock KD, Dishaw LV, Dong W, Hinton DE \& Stapleton HM. Developmental toxicity of the PBDE metabolite 6-OH-BDE-47 in zebrafish and the potential role of thyroid receptor ß. Aquatic Toxicology 2015168 38-47. (https://doi.org/10.1016/j. aquatox.2015.09.007)

363 Ren XM \& Guo LH. Assessment of the binding of hydroxylated polybrominated diphenyl ethers to thyroid hormone transport proteins using a site-specific fluorescence probe. Environmental Science and Technology 201246 4633-4640. (https://doi.org/10.1021/ es2046074)

364 Cao J, Lin Y, Guo LH, Zhang AQ, Wei Y \& Yang Y. Structurebased investigation on the binding interaction of hydroxylated polybrominated diphenyl ethers with thyroxine transport proteins. Toxicology 2010277 20-28. (https://doi.org/10.1016/j. tox.2010.08.012)

365 Roberts SC, Bianco AC \& Stapleton HM. Disruption of type 2 iodothyronine deiodinase activity in cultured human glial cells by polybrominated diphenyl ethers. Chemical Research in Toxicology 2015 28 1265-1274. (https://doi.org/10.1021/acs.chemrestox.5b00072)

366 Marsan ES \& Bayse CA. Halogen-bonding interactions of polybrominated diphenyl ethers and thyroid hormone derivatives: a potential mechanism for the inhibition of iodothyronine deiodinase. Chemistry 201723 6625-6633. (https://doi.org/10.1002/ chem.201700407)

367 Bansal R, Tighe D, Danai A, Rawn DF, Gaertner DW, Arnold DL, Gilbert ME \& Zoeller RT. Polybrominated diphenyl ether (DE-71) interferes with thyroid hormone action independent of effects on circulating levels of thyroid hormone in male rats. Endocrinology 2014 155 4104-4112. (https://doi.org/10.1210/en.2014-1154)

368 Dong W, Macaulay LJ, Kwok KWH, Hinton DE \& Stapleton HM. Using whole mount in situ hybridization to examine thyroid hormone deiodinase expression in embryonic and larval zebrafish a tool for examining OH-BDE toxicity to early life stages. Aquatic Toxicology 2013 132-133 190-199. (https://doi.org/10.1016/j. aquatox.2013.02.008)

369 Geiss O, Tirendi S, Barrero-Moreno J \& Kotzias D. Investigation of volatile organic compounds and phthalates present in the cabin air

http://www.endocrineconnections.org https://doi.org/10.1530/EC-18-0029
() 2018 The authors Published by Bioscientifica Ltd of used private cars. Environment International 200935 1188-1195. (https://doi.org/10.1016/j.envint.2009.07.016)

370 Eckert E, Münch F, Göen T, Purbojo A, Müller J \& Cesnjevar R. Comparative study on the migration of di-2-ethylhexyl phthalate (DEHP) and tri-2-ethylhexyl trimellitate (TOTM) into blood from PVC tubing material of a heart-lung machine. Chemosphere 2016145 10-16. (https://doi.org/10.1016/j.chemosphere.2015.11.067)

371 EFSA. Opinion of the scientific panel on food additives, flavourings, processing aids and materials in contact with food (AFC) on a request from the Commission related to a 5th list of substances for food contact materials. EFSA Journal 20042 109. (https://doi. org/10.2903/j.efsa.2004.109)

372 National Industrial Chemicals Notification and Assessment Scheme (NICNAS). (STD/1259) 1,2-Cyclohexanedicarboxylic acid, 1,2-diisononyl ester ('Hexamoll DINCH'). Sydney, Australia: NICNAS, 2012.

373 Blount BC, Silva MJ, Caudill SP, Needham LL, Pirkle JL, Sampson EJ, Lucier GW, Jackson RJ \& Brock JW. Levels of seven urinary phthalate metabolites in a human reference population. Environmental Health Perspectives 2000108 979-982. (https://doi.org/10.1289/ ehp.00108979)

374 Adibi JJ, Perera FP, Jedrychowski W, Camann DE, Barr D, Jacek R \& Whyatt RM. Prenatal exposures to Phthalates among women in New York and Krakow, Poland. Environmental Health Perspectives 2003111 1719-1722. (https://doi.org/10.1289/ehp.6235)

375 Latini G, De Felice C, Presta G, Del Vecchio A, Paris I, Ruggieri F \& Mazzeo P. In utero exposure to di-(2-ethylhexyl)phthalate and duration of human pregnancy. Environmental Health Perspectives 2003 111 1783-1785. (https://doi.org/10.1289/ehp.6202)

376 Silva MJ, Reidy JA, Herbert AR, Preau JL Jr, Needham LL \& Calafat AM. Detection of phthalate metabolites in human amniotic fluid. Bulletin of Environmental Contamination and Toxicology 200472 1226-1231.

377 Calafat AM, Brock JW, Silva MJ, Gray LE Jr, Reidy JA, Barr DB \& Needham LL. Urinary and amniotic fluid levels of phthalate monoesters in rats after the oral administration of di(2-ethylhexyl) phthalate and di-n-butyl phthalate. Toxicology 2006217 22-30. (https://doi.org/10.1016/j.tox.2005.08.013)

378 Kim Y, Ha EH, Kim EJ, Park H, Ha M, Kim JH, Hong YC, Chang N \& Kim BN. Prenatal exposure to phthalates and infant development at 6 months: prospective mothers and children's environmental health (MOCEH) study. Environmental Health Perspectives 2011119 1495-1500. (https://doi.org/10.1289/ehp.1003178)

379 Polanska K, Ligocka D, Sobala W \& Hanke W. Phthalate exposure and child development: the Polish Mother and Child Cohort Study. Early Human Development 201490 477-485. (https://doi.org/10.1016/j. earlhumdev.2014.06.006)

380 Téllez-Rojo MM, Cantoral A, Cantonwine DE, Schnaas L, Peterson K, Hu H \& Meeker JD. Prenatal urinary phthalate metabolites levels and neurodevelopment in children at two and three years of age. Science of the Total Environment 2013 461-462 386-390. (https://doi. org/10.1016/j.scitotenv.2013.05.021)

381 Whyatt RM, Liu X, Rauh VA, Calafat AM, Just AC, Hoepner L, Diaz D, Quinn J, Adibi J, Perera FP, et al. Maternal prenatal urinary phthalate metabolite concentrations and child mental, psychomotor, and behavioral development at 3 years of age. Environmental Health Perspectives 2012120 290-295. (https://doi.org/10.1289/ehp.1103705)

382 Minatoya M, Naka Jima S, Sasaki S, Araki A, Miyashita C, Ikeno T, Nakajima T, Goto Y \& Kishi R. Effects of prenatal phthalate exposure on thyroid hormone levels, mental and psychomotor development of infants: the Hokkaido Study on Environment and Children's Health. Science of the Total Environment 2016565 1037-1043. (https:// doi.org/10.1016/j.scitotenv.2016.05.098)

383 Swan SH, Liu F, Hines M, Kruse RL, Wang C, Redmon JB, Sparks A \& Weiss B. Prenatal phthalate exposure and reduced masculine play in 
boys. International Journal of Andrology 201033 259-267. (https://doi. $\operatorname{org} / 10.1111 / \mathrm{j} .1365-2605.2009 .01019 . x)$

384 Miodovnik A, Engel SM, Zhu C, Ye X, Soorya LV, Silva MJ, Calafat AM \& Wolff MS. Endocrine disruptors and childhood social impairment. Neurotoxicology 201132 261-267. (https://doi.org/10.1016/j. neuro.2010.12.009)

385 Cho SC, Bhang SY, Hong YC, Shin MS, Kim BN, Kim JW, Yoo HJ, Cho IH \& Kim HW. Relationship between environmental phthalate exposure and the intelligence of school-age children. Environmental Health Perspectives 2010118 1027-1032. (https://doi.org/10.1289/ ehp.0901376)

386 Chopra V, Harley K, Lahiff M \& Eskenazi B. Association between phthalates and attention deficit disorder and learning disability in U.S. children, 6-15 years. Environmental Research 2014128 64-69. (https://doi.org/10.1016/j.envres.2013.10.004)

387 Huang PC, Kuo PL, Guo YL, Liao PC \& Lee CC. Associations between urinary phthalate monoesters and thyroid hormones in pregnant women. Human Reproduction 200722 2715-2722. (https://doi. org/10.1093/humrep/dem205)

388 Boas M, Frederiksen H, Feldt-Rasmussen U, Skakkebæk NE, Hegedüs L, Hilsted L, Juul A \& Main KM. Childhood exposure to phthalates: associations with thyroid function, insulin-like growth factor I, and growth. Environmental Health Perspectives 2010118 1458-1464. (https://doi.org/10.1289/ehp.0901331)

389 Huang PC, Tsai CH, Liang WY, Li SS, Huang HB \& Kuo PL. Early phthalates exposure in pregnant women is associated with alteration of thyroid hormones. PLOS ONE 201611 e0159398. (https://doi. org/10.1371/journal.pone.0159398)

390 Arbuckle TE, Davis K, Marro L, Fisher M, Legrand M, LeBlanc A, Gaudreau E, Foster WG, Choeurng V, Fraser WD, et al. Phthalate and bisphenol A exposure among pregnant women in Canada - results from the MIREC study. Environment International 201468 55-65. (https://doi.org/10.1016/j.envint.2014.02.010)

391 Cantonwine DE, Cordero JF, Rivera-González LO, Anzalota Del Toro LV, Ferguson KK, Mukherjee B, Calafat AM, Crespo N, JiménezVélez B, Padilla IY, et al. Urinary phthalate metabolite concentrations among pregnant women in Northern Puerto Rico: distribution, temporal variability, and predictors. Environment International 2014 62 1-11. (https://doi.org/10.1016/j.envint.2013.09.014)

392 Swan SH, Sathyanarayana S, Barrett ES, Janssen S, Liu F, Nguyen RH, Redmon JB \& TIDES Study Team. First trimester phthalate exposure and anogenital distance in newborns. Human Reproduction 201530 963-972. (https://doi.org/10.1093/humrep/deu363)

393 Meeker JD, Calafat AM \& Hauser R. Di(2-ethylhexyl) phthalate metabolites may alter thyroid hormone levels in men. Environmental Health Perspectives 2007115 1029-1034. (https://doi.org/10.1289/ ehp.9852)

394 Wu MT, Wu CF, Chen BH, Chen EK, Chen YL, Shiea J, Lee WT, Chao MC \& Wu JR. Intake of phthalate-tainted foods alters thyroid functions in Taiwanese children. PLoS ONE 20138 e55005. (https:// doi.org/10.1371/journal.pone.0055005)

395 De Cock M, De Boer MR, Lamoree M, Legler J \& Van De Bor M. Prenatal exposure to endocrine disrupting chemicals (EDCS) in relation to thyroid hormone levels in infants. Archives of Disease in Childhood 201499 A362.

396 Breous E, Wenzel A \& Loos U. The promoter of the human sodium/ iodide symporter responds to certain phthalate plasticisers. in Molecular and Cellular Endocrinology 2005244 75-78. (https://doi. org/10.1016/j.mce.2005.06.009)

397 Shen O, Du G, Sun H, Wu W, Jiang Y, Song L \& Wang X. Comparison of in vitro hormone activities of selected phthalates using reporter gene assays. Toxicology Letters 2009191 9-14. (https://doi. org/10.1016/j.toxlet.2009.07.019)

398 Zhai W, Huang Z, Chen L, Feng C, Li B \& Li T. Thyroid endocrine disruption in zebrafish larvae after exposure to mono-(2-ethylhexyl)

http://www.endocrineconnections.org https://doi.org/10.1530/EC-18-0029 (c) 2018 The authors Published by Bioscientifica Ltd phthalate (MEHP). PLOS ONE 20149 e92465. (https://doi. org/10.1371/journal.pone.0092465)

399 Liu C, Zhao L, Wei L \& Li L. DEHP reduces thyroid hormones via interacting with hormone synthesis-related proteins, deiodinases, transthyretin, receptors, and hepatic enzymes in rats. Environmental Science and Pollution Research 201522 12711-12719. (https://doi. org/10.1007/s11356-015-4567-7)

400 Houde M, Martin JW, Letcher RJ, Solomon KR \& Muir DCG. Biological monitoring of polyfluoroalkyl substances: a review. Environmental Science and Technology 200640 3463-3473. (https:// doi.org/10.1021/es052580b)

401 Spliethoff HM, Tao L, Shaver SM, Aldous KM, Pass KA, Kannan K \& Eadon GA. Use of newborn screening program blood spots for exposure assessment: declining levels of perfluorinated compounds in New York State infants. Environmental Science and Technology 2008 42 5361-5367. (https://doi.org/10.1021/es8006244)

402 Olsen GW, Mair DC, Church TR, Ellefson ME, Reagen WK, Boyd TM, Herron RM, Medhdizadehkashi Z, Nobiletti JB, Rios JA, et al. Decline in perfluorooctanesulfonate and other polyfluoroalkyl chemicals in American red cross adult blood donors, 2000-2006. Environmental Science and Technology 200842 4989-4995. (https://doi.org/10.1021/ es800071x)

403 Kato K, Wong LY, Jia LT, Kuklenyik Z \& Calafat AM. Trends in exposure to polyfluoroalkyl chemicals in the U.S. population: 1999-2008. Environmental Science and Technology 201145 8037-8045. (https://doi.org/10.1021/es1043613)

404 Olsen GW, Burris JM, Ehresman DJ, Froehlich JW, Seacat AM, Butenhoff JL \& Zobel LR. Half-life of serum elimination of perfluorooctanesulfonate, perfluorohexanesulfonate, and perfluorooctanoate in retired fluorochemical production workers. Environmental Health Perspectives 2007115 1298-1305. (https://doi. org/10.1289/ehp.10009)

$405 \mathrm{Hu} \mathrm{XC}$, Andrews DQ, Lindstrom AB, Bruton TA, Schaider LA, Grandjean P, Lohmann R, Carignan CC, Blum A, Balan SA, et al. Detection of Poly- and Perfluoroalkyl Substances (PFASs) in U.S. drinking water linked to industrial sites, military fire training areas, and wastewater treatment plants. Environmental Science and Technology Letters 20163 344-350. (https://doi.org/10.1021/acs. estlett.6b00260)

406 Johansson N, Fredriksson A \& Eriksson P. Neonatal exposure to perfluorooctane sulfonate (PFOS) and perfluorooctanoic acid (PFOA) causes neurobehavioural defects in adult mice. Neurotoxicology 2008 29 160-169. (https://doi.org/10.1016/j.neuro.2007.10.008)

407 Slotkin TA, MacKillop EA, Meinick RL, Thayer KA \& Seidler FJ. Developmental neurotoxicity of perfluorinated chemicals modeled in vitro. Environmental Health Perspectives 2008116 716-722. (https:// doi.org/10.1289/ehp.11253)

408 Gizer IR, Ficks C \& Waldman ID. Candidate gene studies of ADHD: a meta-analytic review. Human Genetics 2009126 51-90. (https://doi. org/10.1007/s00439-009-0694-x)

409 Faraone SV, Perlis RH, Doyle AE, Smoller JW, Goralnick JJ, Holmgren MA \& Sklar P. Molecular genetics of attention-deficit/ hyperactivity disorder. Biological Psychiatry 200557 1313-1323. (https://doi.org/10.1016/j.biopsych.2004.11.024)

410 Hoffman K, Webster TF, Weisskopf MG, Weinberg J \& Vieira VM. Exposure to polyfluoroalkyl chemicals and attention deficit/ hyperactivity disorder in U.S. children $12-15$ years of age. Environmental Health Perspectives 2010118 1762-1767. (https://doi. org/10.1289/ehp.1001898)

411 Stein CR \& Savitz DA. Serum perfluorinated compound concentration and attention deficit/hyperactivity disorder in children 5-18 years of age. Environmental Health Perspectives 2011119 1466-1471. (https://doi.org/10.1289/ehp.1003538)

412 Gump BB, Wu Q, Dumas AK \& Kannan K. Perfluorochemical (PFC) exposure in children: associations with impaired response inhibition. 
Environmental Science and Technology 201145 8151-8159. (https:// doi.org/10.1021/es103712g)

413 Fei C, McLaughlin JK, Lipworth L \& Olsen J. Prenatal exposure to perfluorooctanoate (PFOA) and perfluorooctanesulfonate (PFOS) and maternally reported developmental milestones in infancy. Environmental Health Perspectives 2008116 1391-1395. (https://doi. org/10.1289/ehp.11277)

414 Fei C \& Olsen J. Prenatal exposure to perfluorinated chemicals and behavioral or coordination problems at age 7 years. Environmental Health Perspectives 2011119 573-578. (https://doi.org/10.1289/ ehp.1002026)

415 Endendijk JJ, Wijnen HAA, Pop VJM \& van Baar AL. Maternal thyroid hormone trajectories during pregnancy and child behavioral problems. Hormones and Behavior 201794 84-92. (https://doi. org/10.1016/j.yhbeh.2017.06.007)

416 Modesto T, Tiemeier H, Peeters RP, Jaddoe VW, Hofman A, Verhulst FC \& Ghassabian A. Maternal mild thyroid hormone insufficiency in early pregnancy and attention-deficit/hyperactivity disorder symptoms in children. JAMA Pediatrics 2015169 838-845. (https://doi.org/10.1001/jamapediatrics.2015.0498)

417 Hauser P, Zametkin AJ, Martinez P, Vitiello B, Matochik JA, Mixson AJ $\&$ Weintraub BD. Attention deficit-hyperactivity disorder in people with generalized resistance to thyroid hormone. New England Journal of Medicine 1993328 997-1001. (https://doi.org/10.1056/ NEJM199304083281403)

418 Pearce EN. Maternal hypothyroxinemia in pregnancy is associated with increased risk for ADHD symptoms in children. Clinical Thyroidology 201527 212-214. (https://doi.org/10.1089/ct.2015;27.212-214)

419 Olsen GW \& Zobel LR. Assessment of lipid, hepatic, and thyroid parameters with serum perfluorooctanoate (PFOA) concentrations in fluorochemical production workers. International Archives of Occupational and Environmental Health 200781 231-246. (https://doi. org/10.1007/s00420-007-0213-0)

420 Melzer D, Rice N, Depledge MH, Henley WE \& Galloway TS. Association between serum perfluorooctanoic acid (PFOA) and thyroid disease in the U.S. National Health and Nutrition Examination Survey. Environmental Health Perspectives 2010118 686-692. (https://doi.org/10.1289/ehp.0901584)

421 Chang SC, Thibodeaux JR, Eastvold ML, Ehresman DJ, Bjork JA, Froehlich JW, Lau CS, Singh RJ, Wallace KB \& Butenhoff JL. Negative bias from analog methods used in the analysis of free thyroxine in rat serum containing perfluorooctanesulfonate (PFOS). Toxicology 2007234 21-33. (https://doi.org/10.1016/j.tox.2007.01.020)

422 Martin MT, Brennan RJ, Hu W, Ayanoglu E, Lau C, Ren H, Wood CR, Corton JC, Kavlock RJ \& Dix DJ. Toxicogenomic study of triazole fungicides and perfluoroalkyl acids in rat livers predicts toxicity and categorizes chemicals based on mechanisms of toxicity. Toxicological Sciences 200797 595-613. (https://doi.org/10.1093/toxsci/kfm065)

423 Seacat AM, Thomford PJ, Hansen KJ, Clemen LA, Eldridge SR, Elcombe CR \& Butenhoff JL. Sub-chronic dietary toxicity of potassium perfluorooctanesulfonate in rats. Toxicology $2003 \mathbf{1 8 3}$ 117-131. (https://doi.org/10.1016/S0300-483X(02)00511-5)

424 Thibodeaux JR, Hanson RG, Rogers JM, Grey BE, Barbee BD, Richards JH, Butenhoff JL, Stevenson LA \& Lau C. Exposure to perfluorooctane sulfonate during pregnancy in rat and mouse. I: maternal and prenatal evaluations. Toxicological Sciences $2003 \mathbf{7 4}$ 369-381. (https://doi.org/10.1093/toxsci/kfg121)

425 Lau C, Thibodeaux JR, Hanson RG, Rogers JM, Grey BE, Stanton ME, Butenhoff JL \& Stevenson LA. Exposure to perfluorooctane sulfonate during pregnancy in rat and mouse. II: postnatal evaluation. Toxicological Sciences 200374 382-392. (https://doi.org/10.1093/ toxsci/kfg122)

426 Yu WG, Liu W, Jin Y-H, Liu X-H, Wang F-Q, Liu L \& Nakayama SF. Prenatal and postnatal impact of perfluorooctane sulfonate (PFOS) on rat development: a cross-foster study on chemical burden and thyroid hormone system. Environmental Science and Technology 2009 43 8416-8422. (https://doi.org/10.1021/es901602d)

427 Luebker DJ, York RG, Hansen KJ, Moore JA \& Butenhoff JL. Neonatal mortality from in utero exposure to perfluorooctanesulfonate (PFOS) in Sprague-Dawley rats: dose-response, and biochemical and pharamacokinetic parameters. Toxicology 2005215 149-169. (https:// doi.org/10.1016/j.tox.2005.07.019)

428 Weiss JM, Andersson PL, Lamoree MH, Leonards PE, van Leeuwen SP \& Hamers T. Competitive binding of poly- and perfluorinated compounds to the thyroid hormone transport protein transthyretin. Toxicological Sciences 2009109 206-216. (https://doi.org/10.1093/ toxsci/kfp055)

429 Yu WG, Liu W \& Jin YH. Effects of perfluorooctane sulfonate on rat thyroid hormone biosynthesis and metabolism. Environmental Toxicology and Chemistry 200828 1. (https://doi.org/10.1897/08345.1)

430 Delfosse V, Dendele B, Huet T, Grimaldi M, Boulahtouf A, GerbalChaloin S, Beucher B, Roecklin D, Muller C, Rahmani R, et al. Synergistic activation of human pregnane $\mathrm{X}$ receptor by binary cocktails of pharmaceutical and environmental compounds. Nature Communications 20156 8089. (https://doi.org/10.1038/ncomms9089)

431 Silva E, Rajapakse N \& Kortenkamp A. Something from 'nothing' eight weak estrogenic chemicals combined at concentrations below NOECs produce significant mixture effects. Environmental Science and Technology 200236 1751-1756. (https://doi.org/10.1021/es0101227)

432 Fini J-B, Mughal BB, Le Mével S, Leemans M, Lettmann M, Spirhanzlova P, Affaticati P, Jenett A \& Demeneix BA. Human amniotic fluid contaminants alter thyroid hormone signalling and early brain development in Xenopus embryos. Scientific Reports 2017 7 43786. (https://doi.org/10.1038/srep43786)

433 Birgersson L, Borbely G, Caporale N, Germain P-L, Leemans M, Rendel F, D'Agostino G, Bardini Bressan R, Cavallo F, Even Chorev N, et al. From cohorts to molecules: adverse impacts of endocrine disrupting mixtures. bioRxiv 2017 206664. (https://doi. org/10.1101/206664)

Received in final form 4 March 2018

Accepted 14 March 2018 http://www.endocrineconnections.org https://doi.org/10.1530/EC-18-0029
() 2018 The authors Published by Bioscientifica Ltd
This work is licensed under a Creative Commons Attribution-NonCommercial-NoDerivatives 4.0 International License. 